ピューリタン革命期に肪ける和等派の法思想の序論的研究

な進我のの内法後ン思定續化 い九或諸英面思米想足想さピ

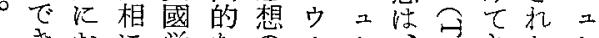

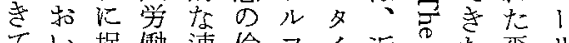
てい捉働連倫フイ近。た平り

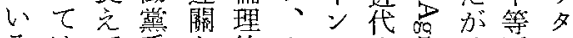

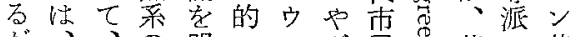
が、、の明・ッグ民莫英の革

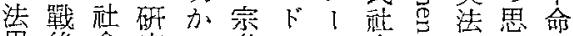
思兴會究に教八千會分想の 想、經者乙的比像果に注激

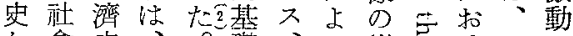

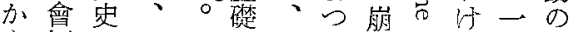
ら經の本まに八て壊する九な

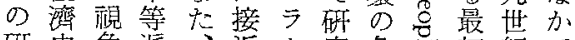
研定角派、近 1 究危氖初紀で 究のかのヒし、の機、の本急

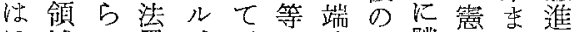

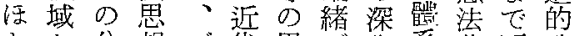
とか分想ブ代思が化系草魔政 んら析をラ民想開索化案串治

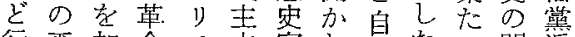
行平加命ス圭家机覺たる䦍派 な等克思フ義はた學平、のと

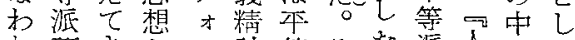
れ研きと、神等そた派人にて

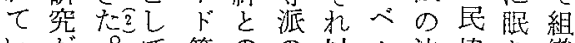
いが。乙等のの以ル法協り織

と!的るがは法請形化㲀な、跡

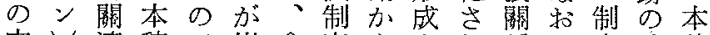
内 連稿で崩妾度らされ係加度遍稿

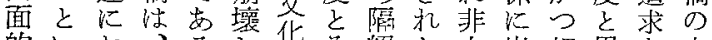

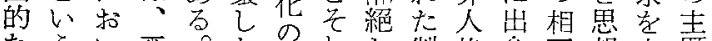
な 5 心平。た悲れし制格會互想主題

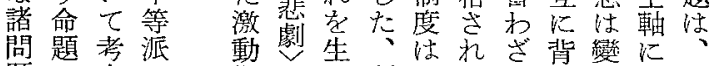

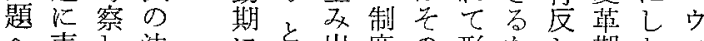
ヘ表乙法に出度の形をし期たす

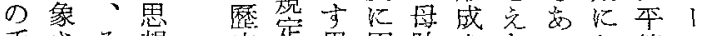
手さを想吏定思固胎さない特等心

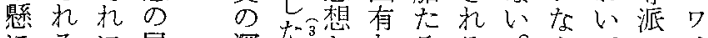

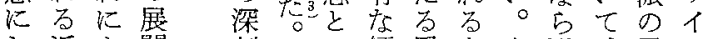

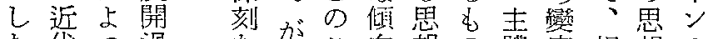
た代つ過なかっこ向想の賠容相想の W部て程必一の性のがのし互の抵

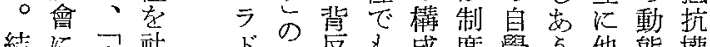

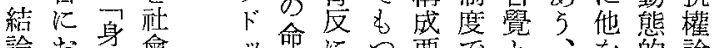

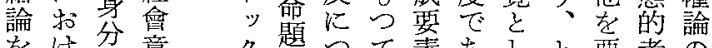

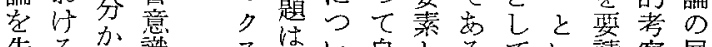

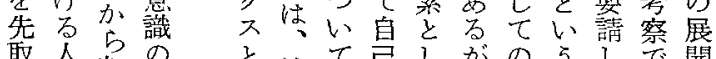
取人契の と法て芑しがの5しで開

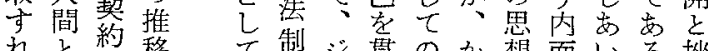

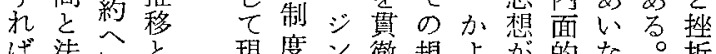
ば法乞と現度ン徹規よが的な。折 、制へのわのメ方範 5 客なが の 本度名内狆たル方要に體緊! 軌

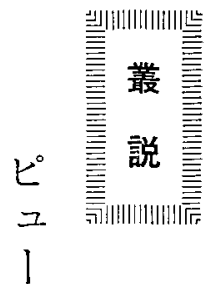

1)

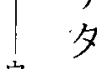

ウ

リ莗

么 仰

- 期

少记

拉

几 H

1 万

弟平

抵等

抗 派

をの

心法

思

七 想 の

序

小論

的

池 研

究

EF

行 
張はたミ

安宗?

数指比

长立摘少

同性乞

時㤎心素

代相る教

标皇学等

七鼠々

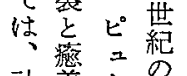

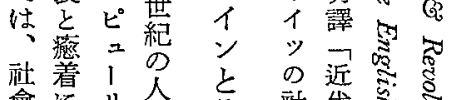

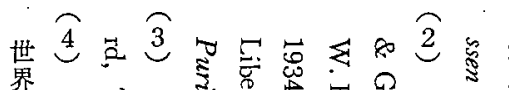

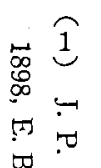

あ制り等

る度 1 派

意思

い味想

$\tau+o$

のる展

深飞開

w考家

問灾挫

題 5 折

を礼の

投る過

济が程

てゅ性

以充

る紧京

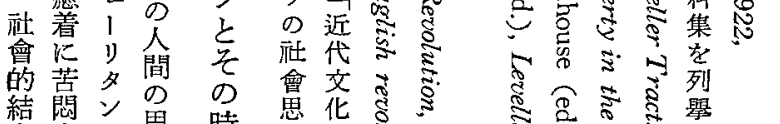

合专革思

社学命期会

會心等慣

構 5 社 用

成 兰會語

の重ので

基の精あ

本緊祍

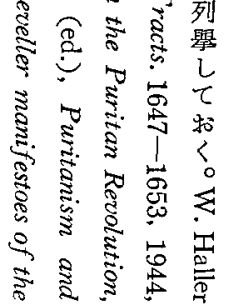

过机标

と代 社

考 觡. 會

克 會 整

らに約

れ招論

るけの

少工

ら法口

でとラ

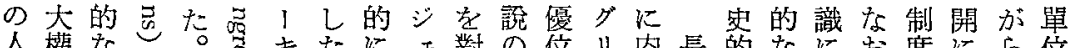

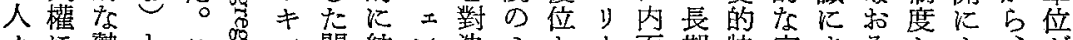

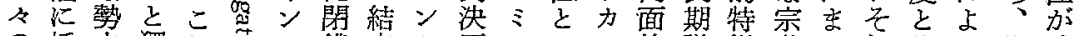

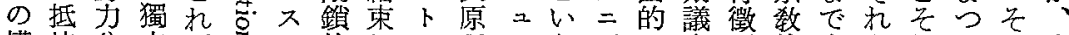

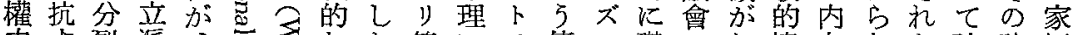

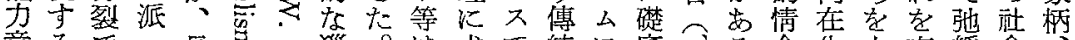

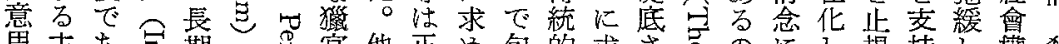

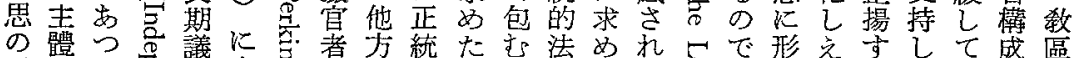

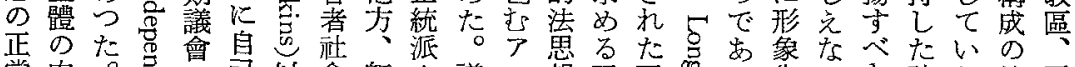

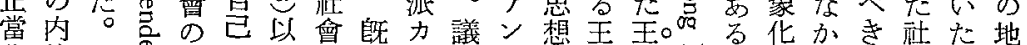

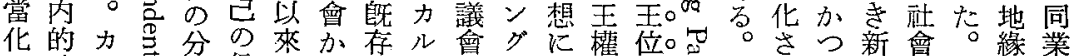

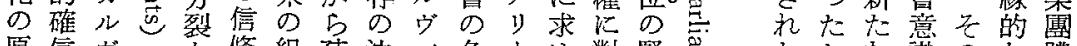

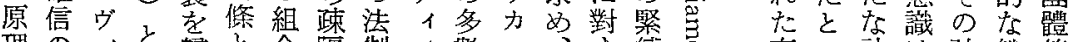

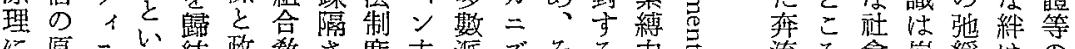
に原二ら結政数さ度主派ズそる力流ら會崩緩はの

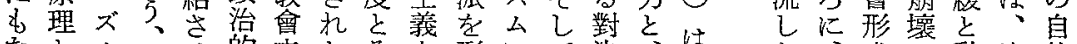

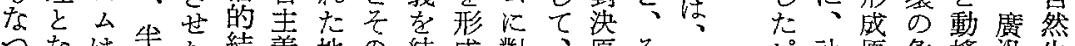
つなは牛た結義地の結成對、原々自比原危摇沉䅉 たるか、字長合力方下合乞し國理の自然會理機にな的

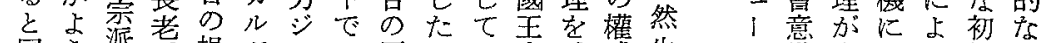
同 5 派派嫢ヴェの原口力方留生識客陷り期生

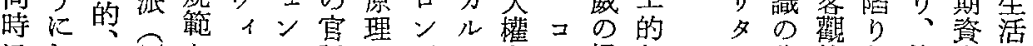
にし里をこト起をドウをを根な分的な傳本圈

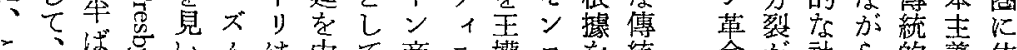

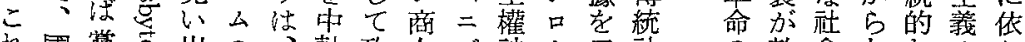

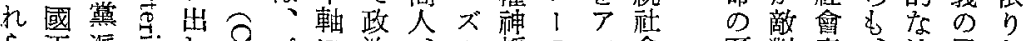

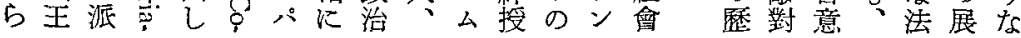




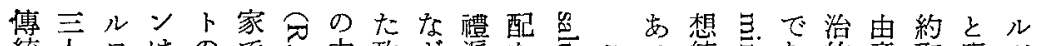

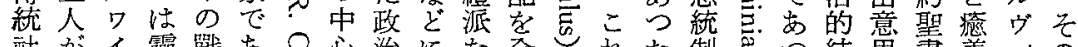

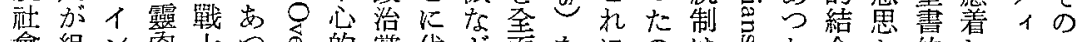

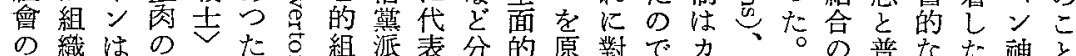
の織はのたた鸟組派表分的原對で力、。の普なた神々

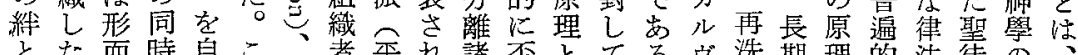
とた而時自こ、者平れ諸否とて省ら洗期理的法徒の

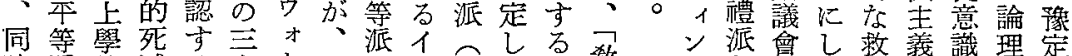

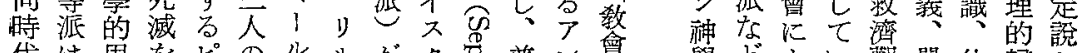

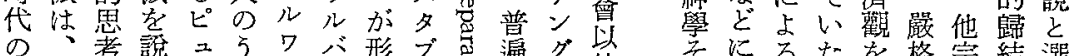

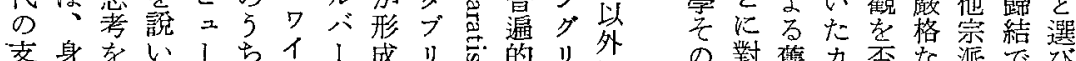

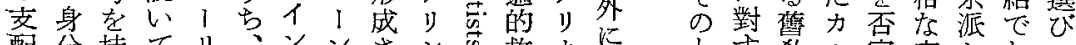

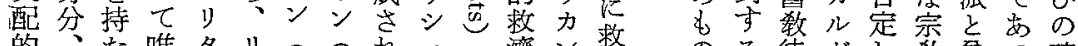

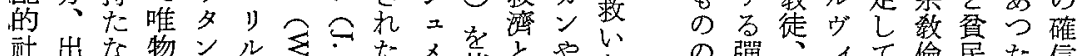

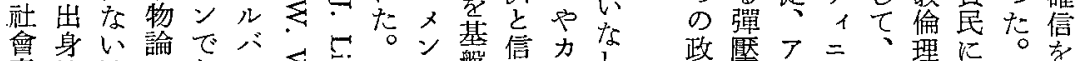

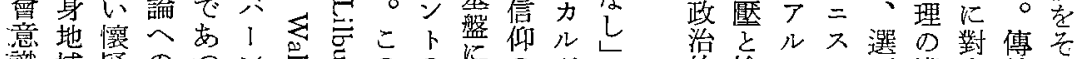

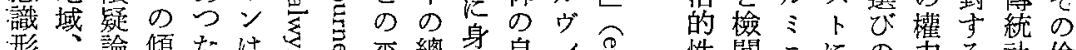

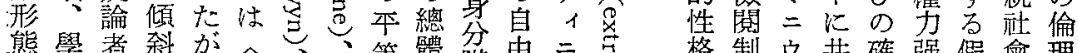

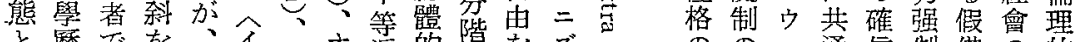

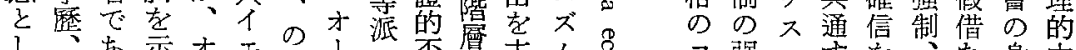

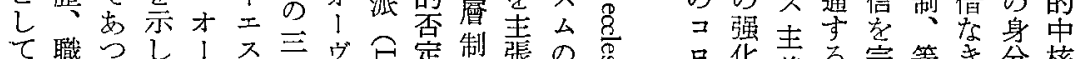

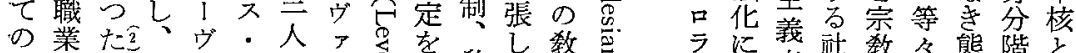
宗等

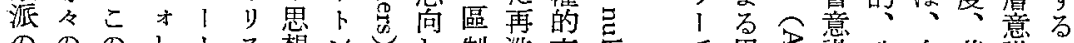

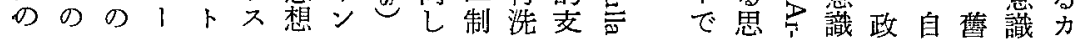

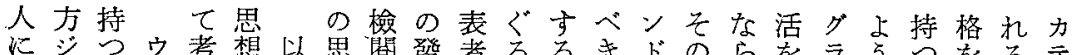

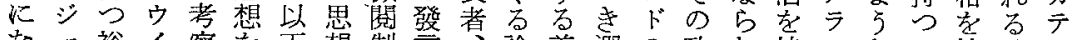
な土裕イ察を卡想制言論義選の政な持ンなて持社ゴ りン福りし展、家のにレ爭務舉い府いつド平いつ會り

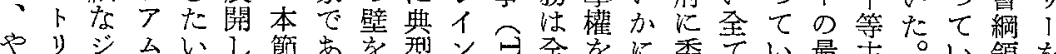

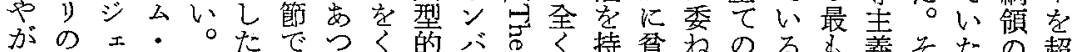

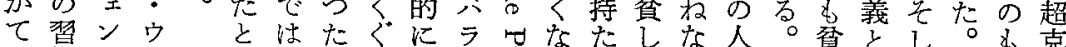

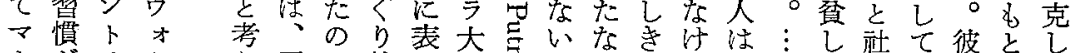
I

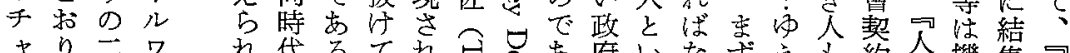

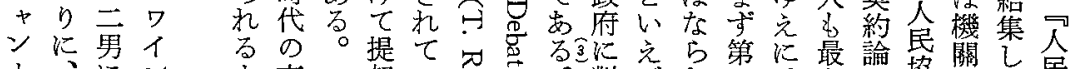

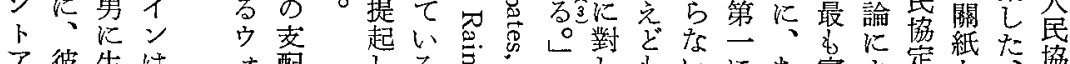

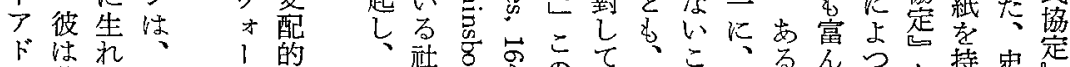
はれ

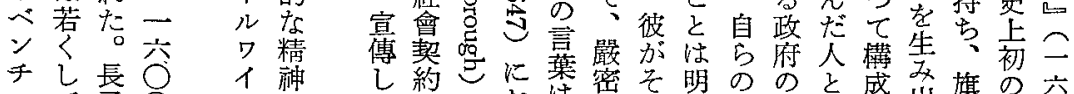

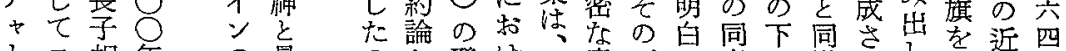

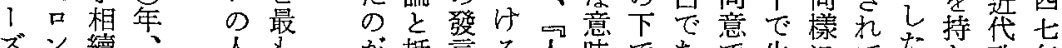
ズン續、㐫方抵言る人味であで生にて染ち政年

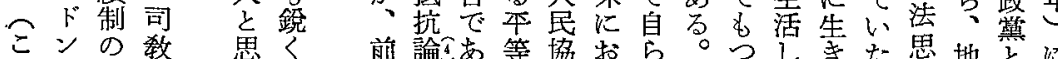

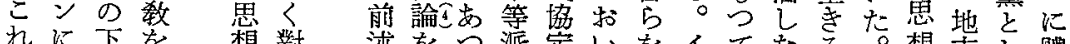

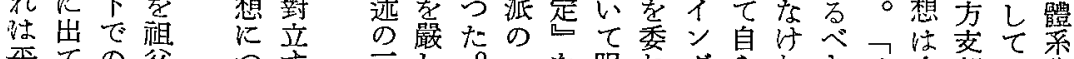

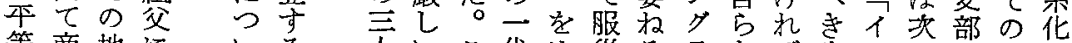

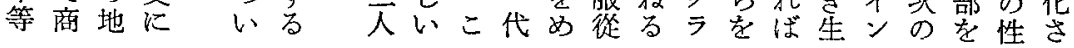


教をさ定スもしこ壳動同會でこ去をさは衝界、想派

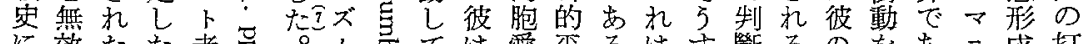

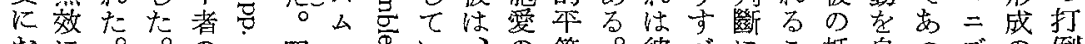

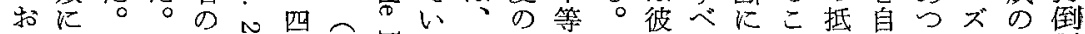
いで てき

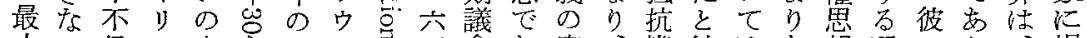

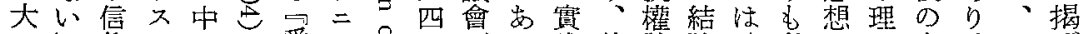

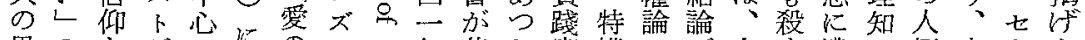

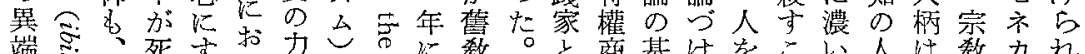

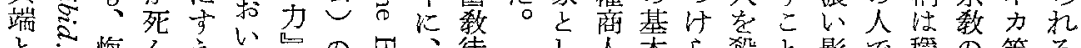

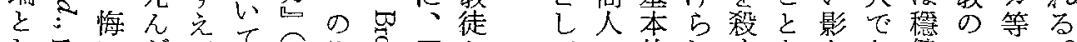

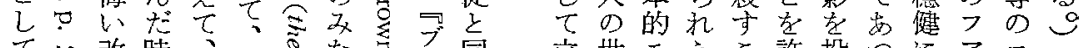

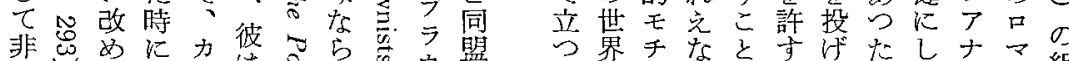

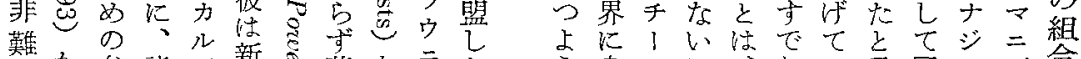

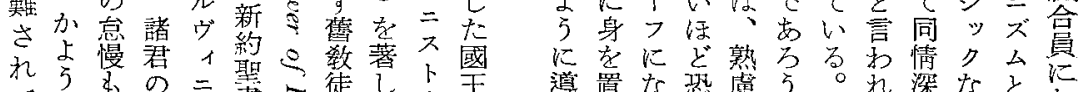

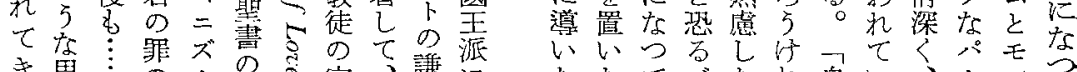

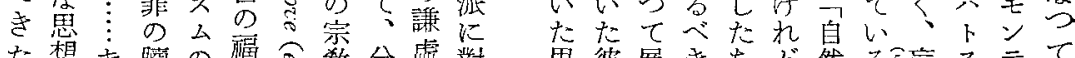

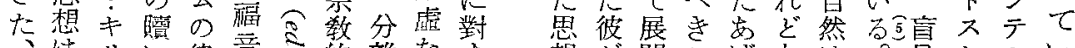
、性、以律音さ的離な专 反、スの法主。自派請石

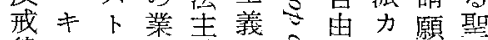

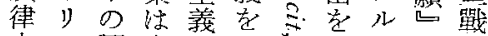

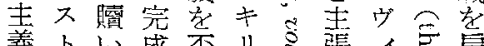

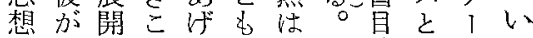

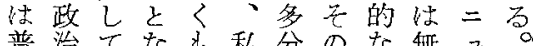
普治てな 私分のな無二品 遍的いの已の私人情緣 的、たた包良飞間念の七の な社のしは心殺性の世二思

て彼ン律彼で人原前と律么義が彼慨制あかのにるる

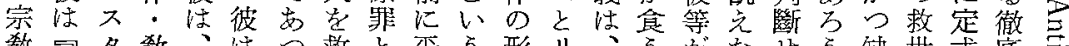

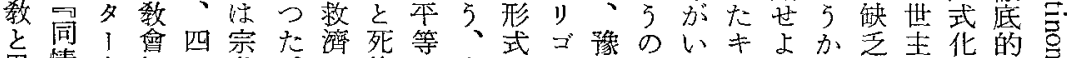

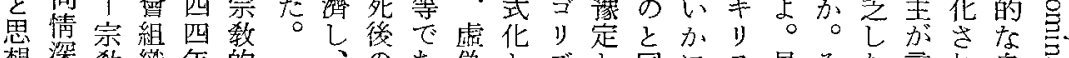
想深教 織 年 的 にき會等に自 對节議の、旦 守 $\checkmark$ 在 議

る リミり㹕概

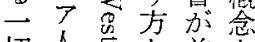

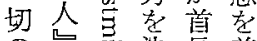
の号決長普 權念量定敉萹

力 到守會的

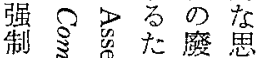

を想

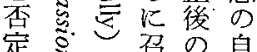

定きの召の自

た。 權し教の

。等威金原

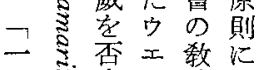

马定

の

强した心規た

、あ偽とズと同にス見そた言れ自总

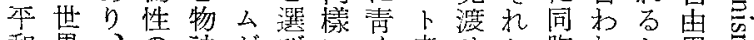
和界、の湤がびにく者せ加胞れと思哥 をの現批化有に食弱た。らを給き想

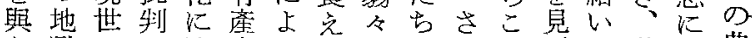

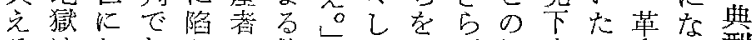

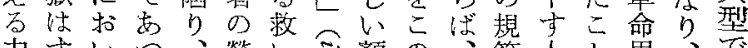
力すい口、營い念顏の、範人之思、で

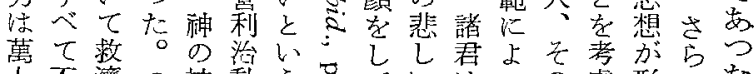

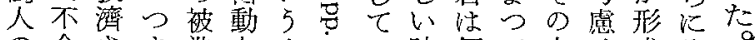
の合さ变造艺力心時何て人せ成々 心理るり者義山岕当代千誰の吉されそ のとベ、で認ヴ!ののと怔な。れがれ

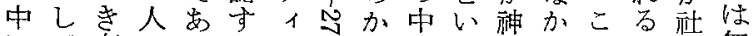
にて存はるるニさをに5のにのの會無 存否在全頚々ズ彼見見悲家神世で的砷

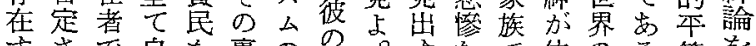

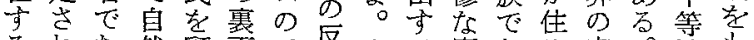

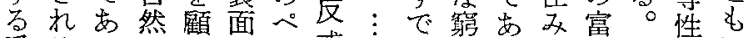

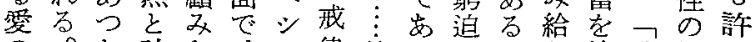
の。た神な、ミ律彼万しから持我規容 力萬。のい成ズ主等 5 たをで範尌 
シにドド的區論は彼思党たでしに宗ざも治化 5 制 テ對ウウ自制ウ者もは想なめ女た駱派るに批の彼孯は

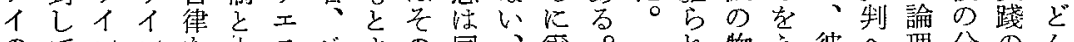

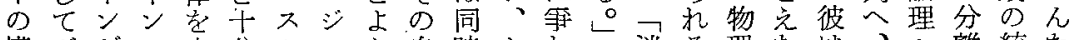
權 グがの圭分トェり自時とわ㴹る理なは、へ離統な 力ッ指大張のミス、旦代私な私信。的く激信と諸合方

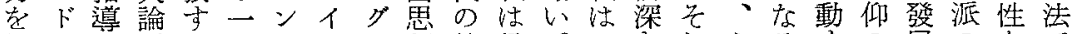

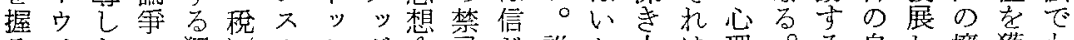

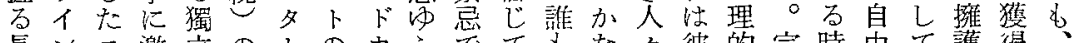

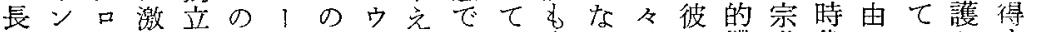

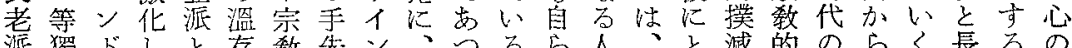

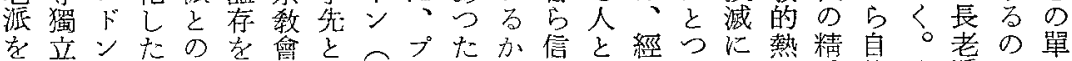

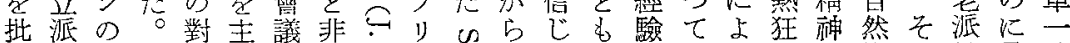

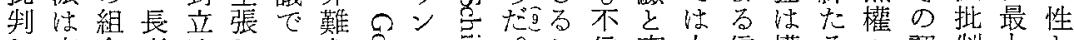

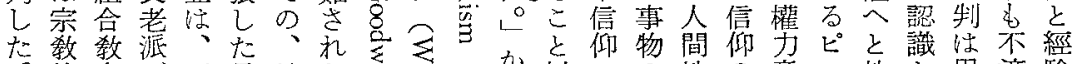

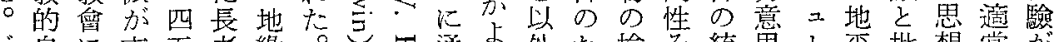

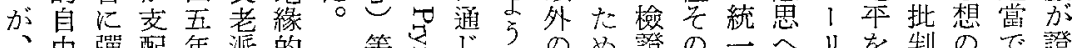

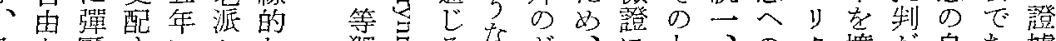

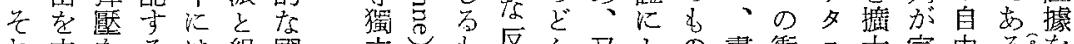

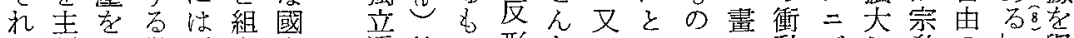
は張方議プ合敎派等の形なはつの動ズし教のし與 $\checkmark$ L H 會 y教會 長てたはン會組 老議。、對の織 源 會こググ相 加長て而こ異て否化をムて批原

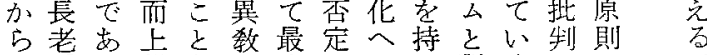

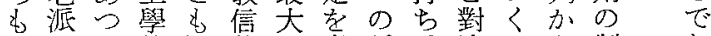
無加た的潠仰の意誘、決々ら制市 と机ッッ對敉神ら。な゙の敵味惑他せと政度る

エ言に我ギ上れ筣敎なに人シたはのもきた統こ宗の

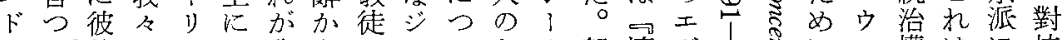

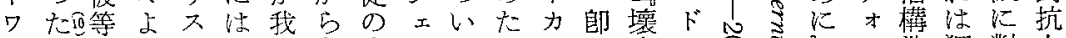

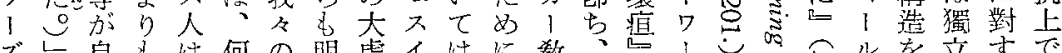

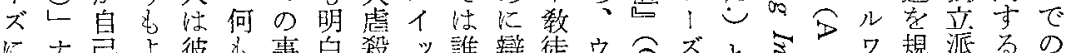

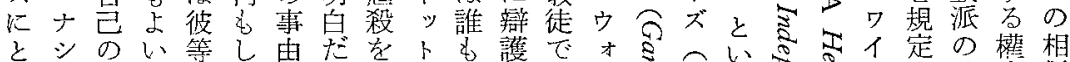

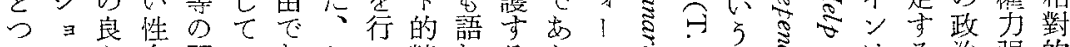

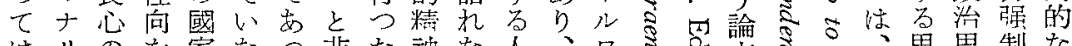

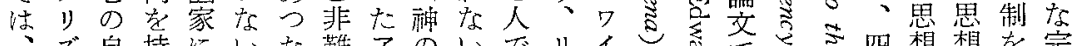

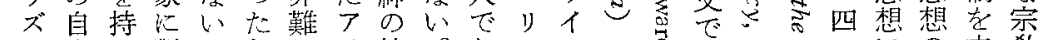

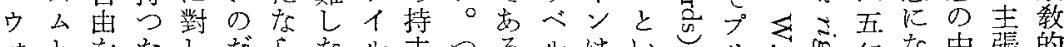

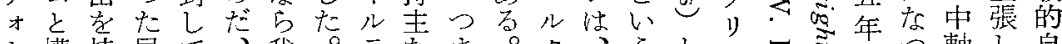

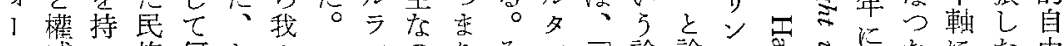

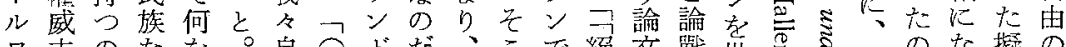

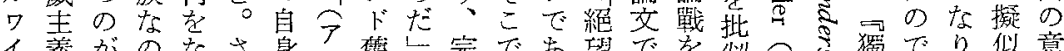

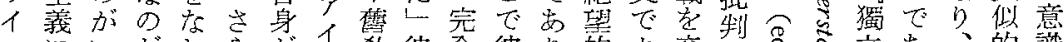
ソにWた乚

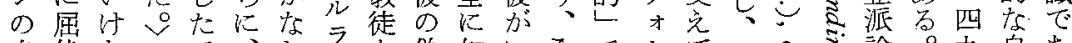

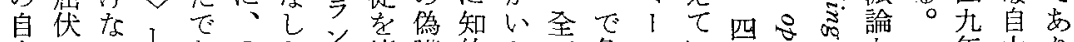

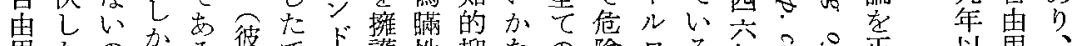

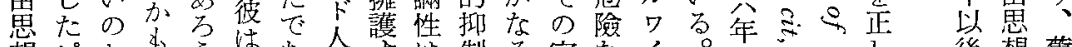

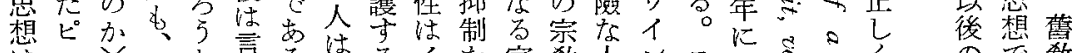

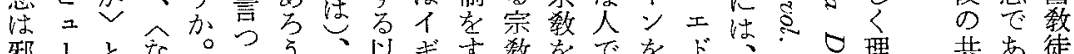

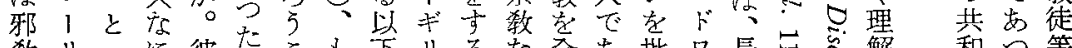

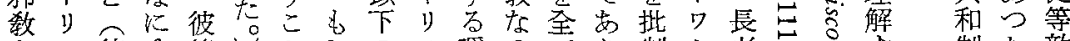

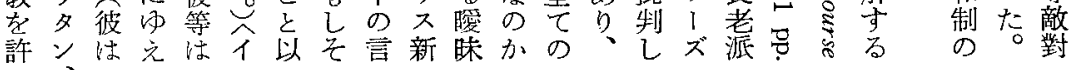




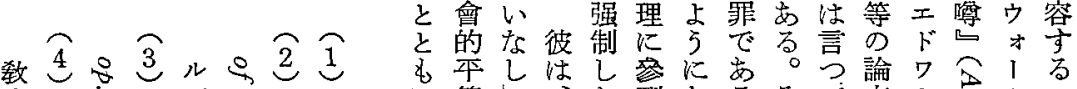

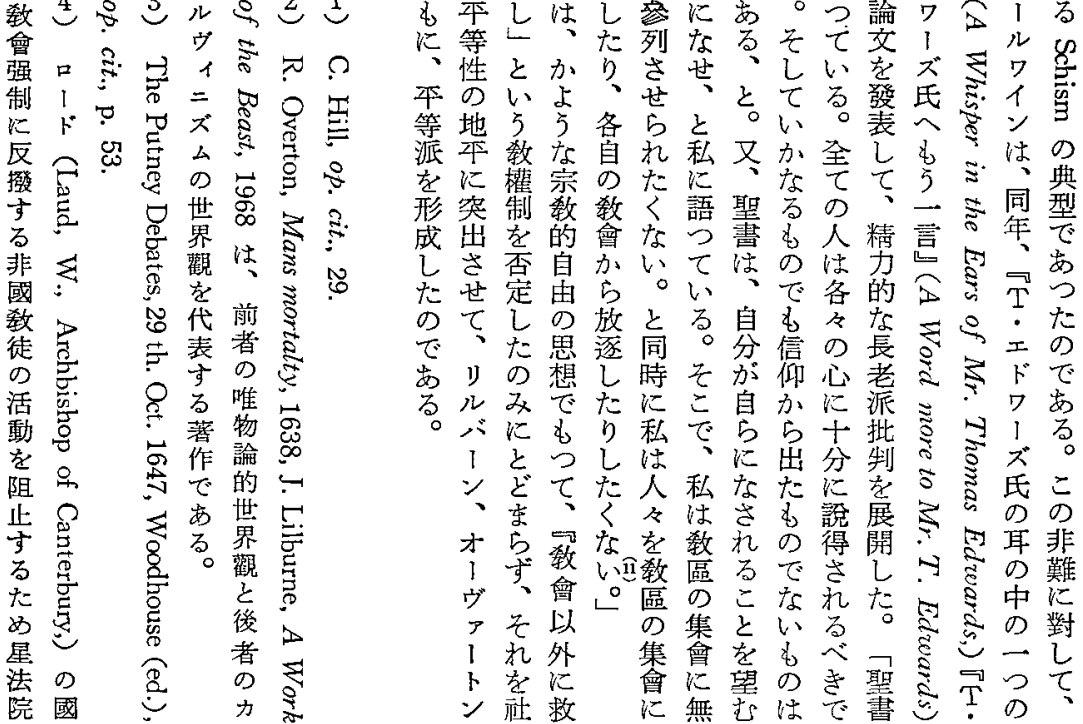

議誇國者さ主卜美基す

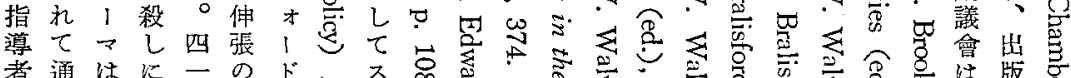

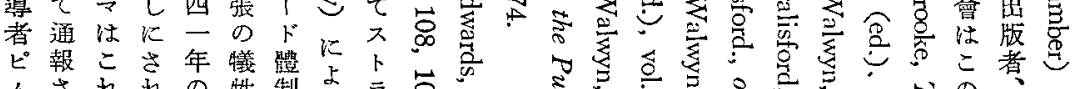

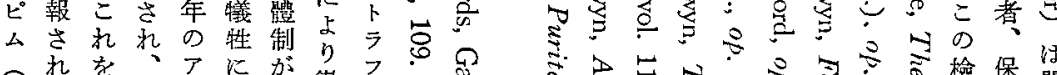

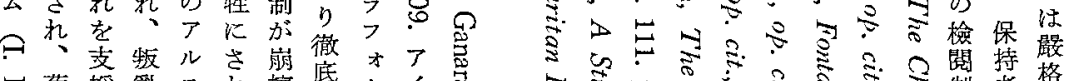

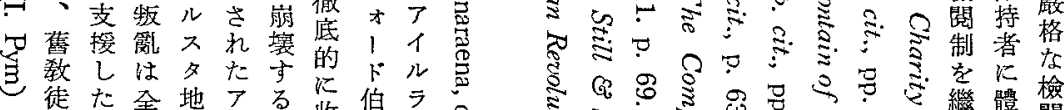

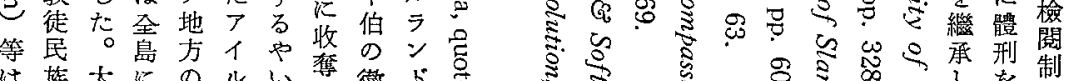

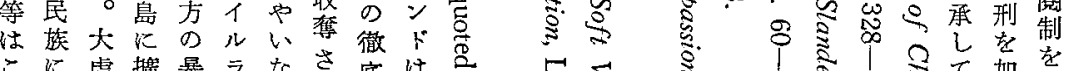

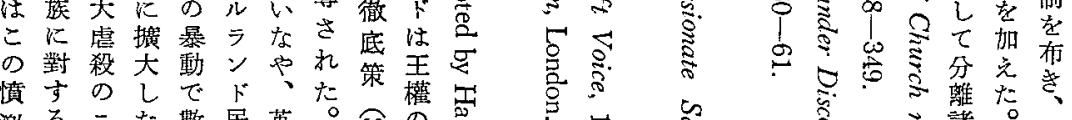
激る二た數 民英。② 忿

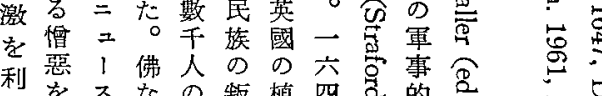

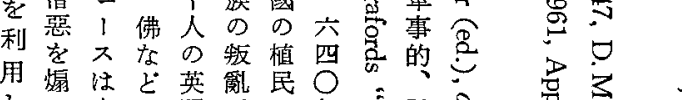

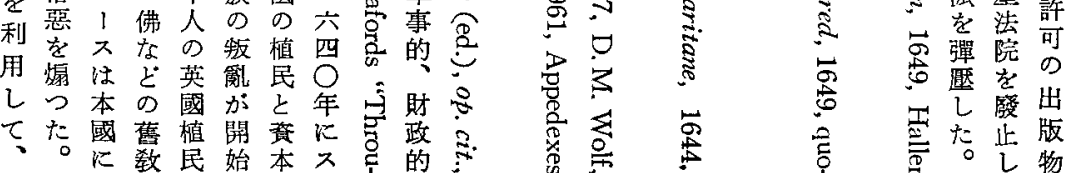


ピューリタン革命期における本等派の法思想の序論的䃊究

なて五

否共年り

定衝 ごル

原活乃

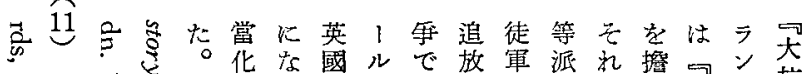

理動が

る入議、

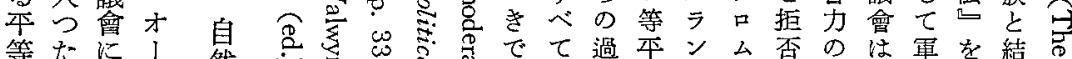

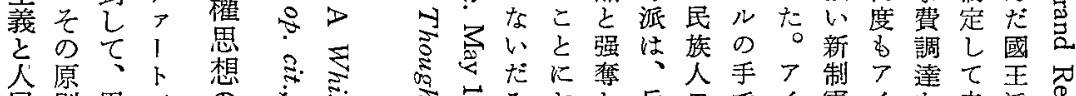

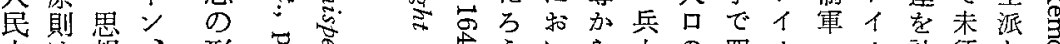

表想、形? す

權躯言

論既言 オ

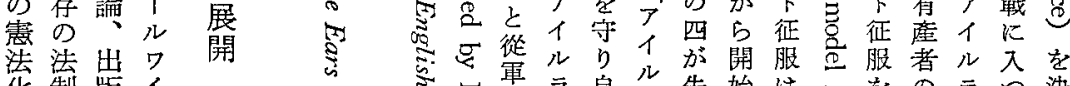

化制版

へ度のン

との自の

普 ラ冎

遍デ学人

华力挍濩

るル 四

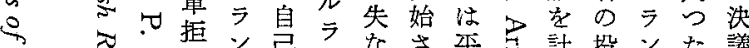

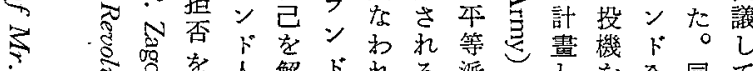

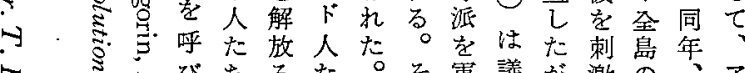

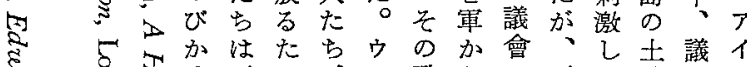

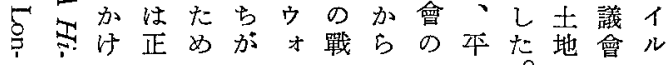

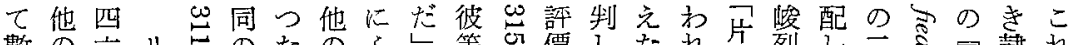

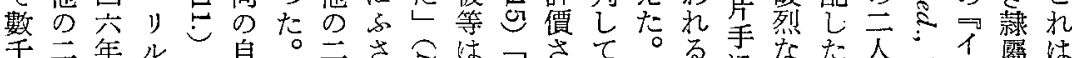

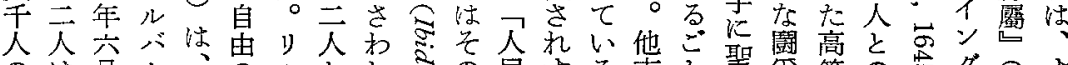
のは含 1 平雜

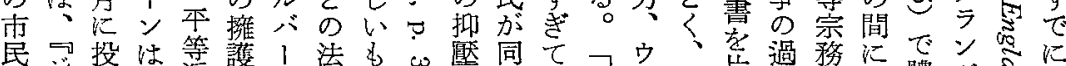

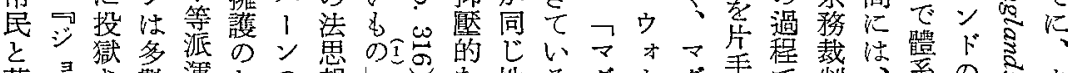

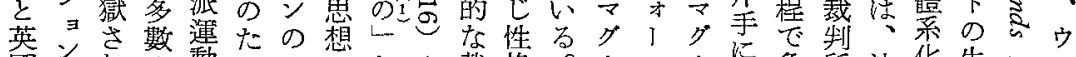

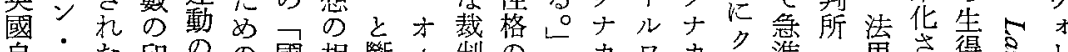

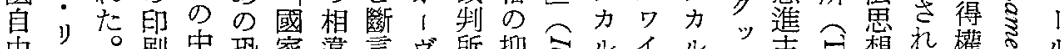

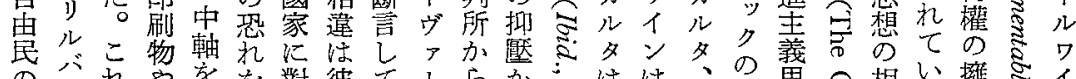

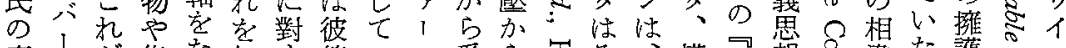

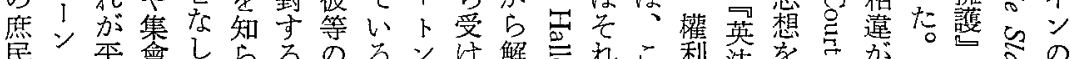

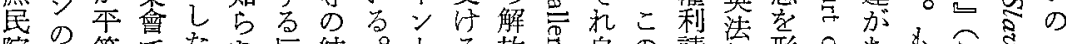

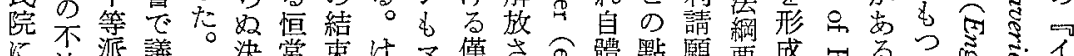
對法運 會

高栾動 攻

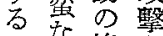

抗投烽孝

議 魰 火 續

孰讨

可なた

苗あつた

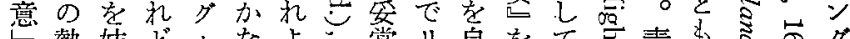

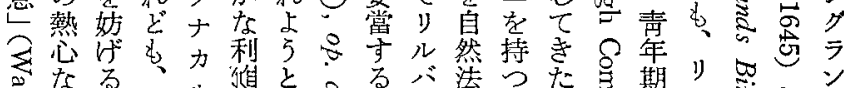

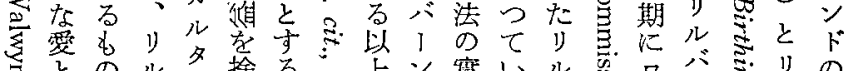

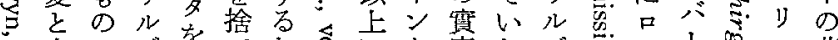

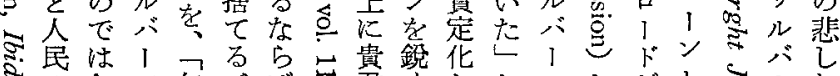

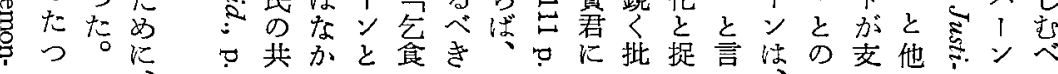




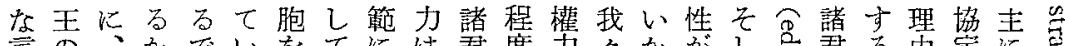

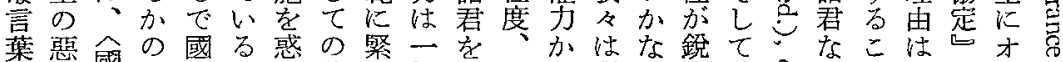

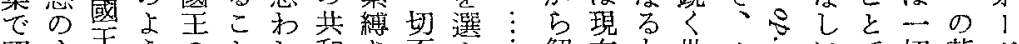

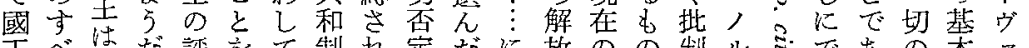
온

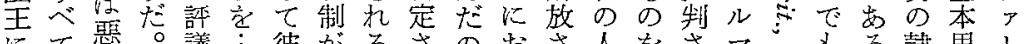

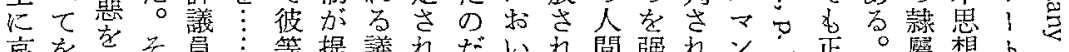

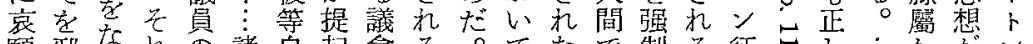

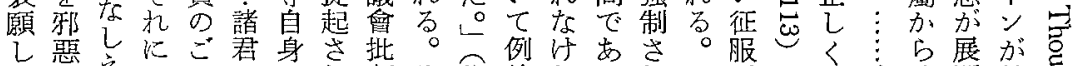

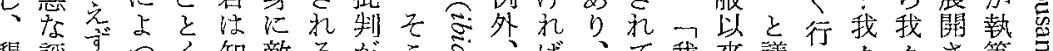

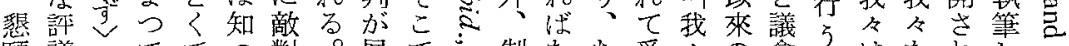

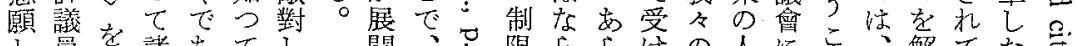

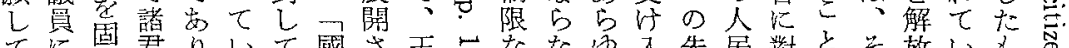

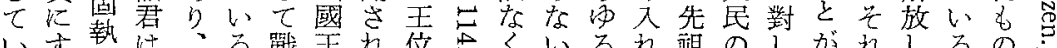

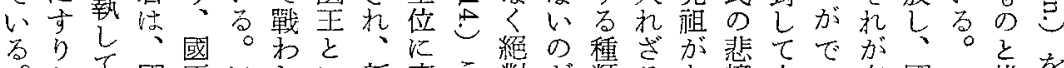

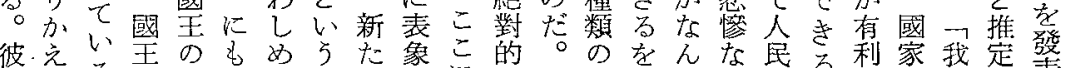

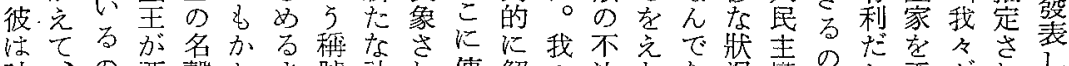

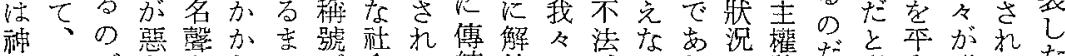

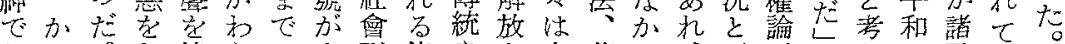

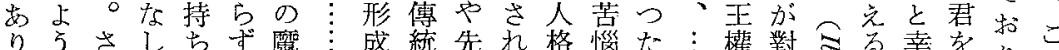

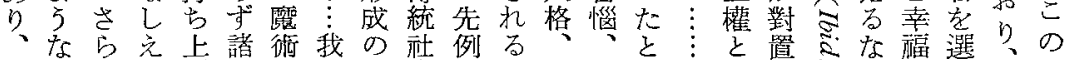

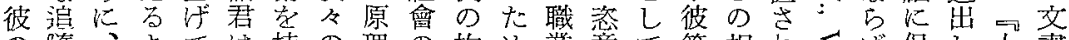

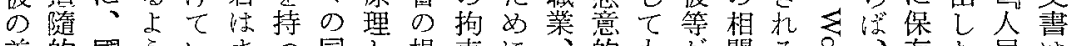

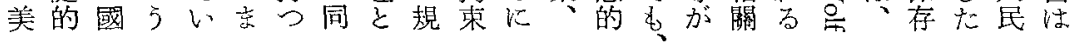

だる琵市儿君展投的前病がの議こ 生导る縛に開魰性に人そ特會で批。今゙せな代決にな 郎業るこり、ささ格ひ、の權はは判へるざ征表しはし

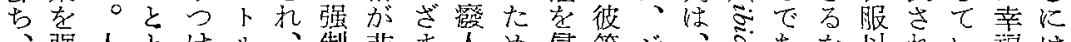

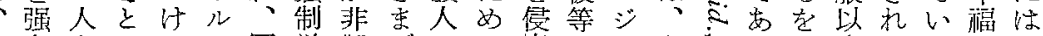

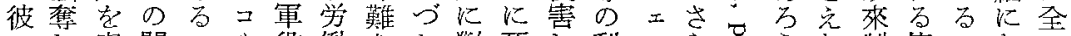

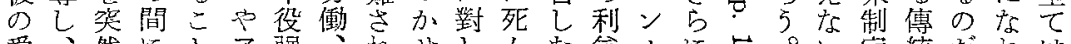

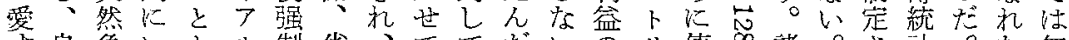

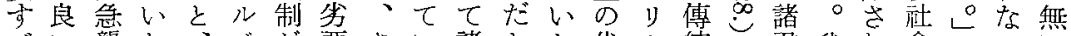

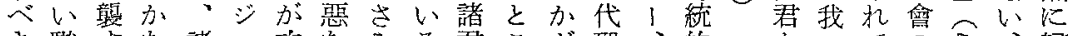

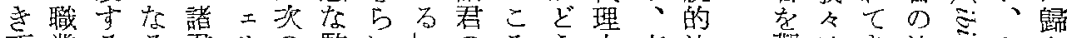

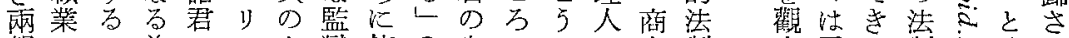

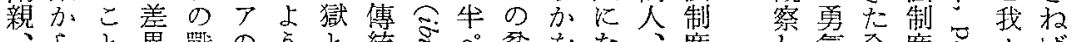

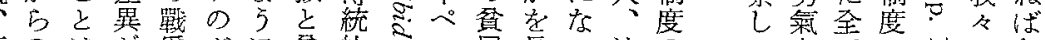

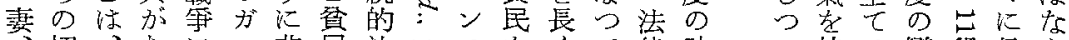
切、支にレ非民法り

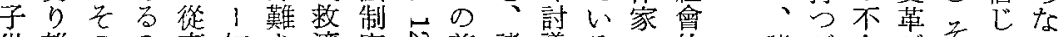

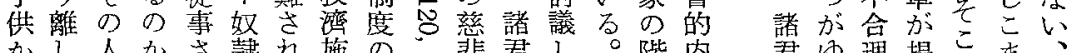

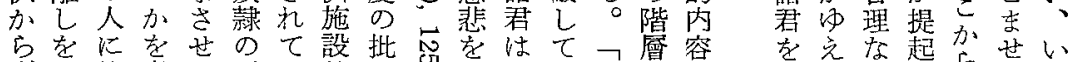

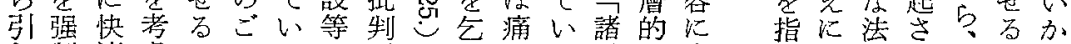

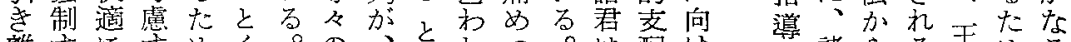

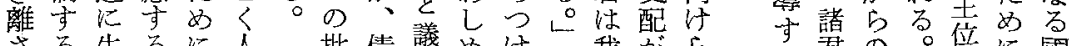

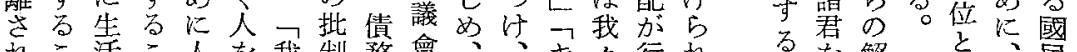

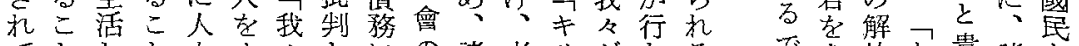

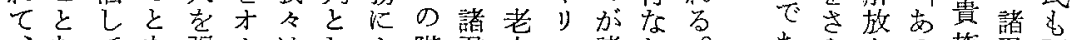

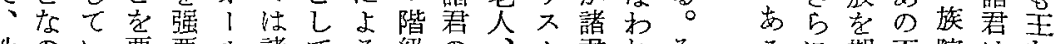
性のい要要ル諸てる級の、ト君れそるに期不院はね 
兵ン軍じ 禁監廢英五のがの三高態のたでびにを向

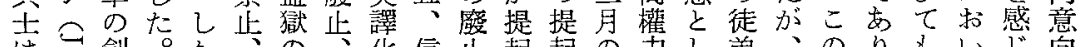

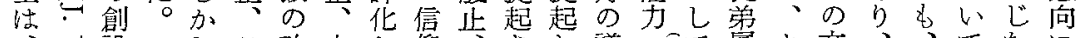

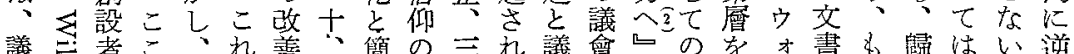

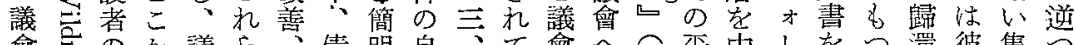

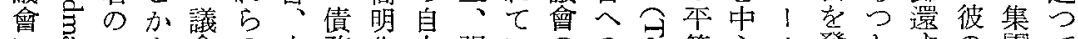

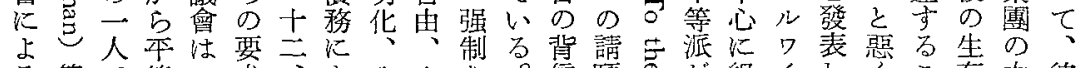

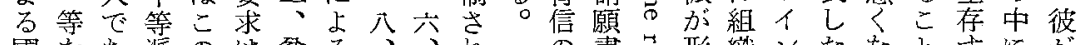

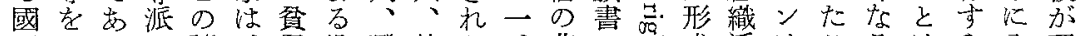
王とつは請、邑投證特た、非に寻成活はこるはら入理

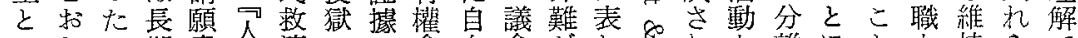

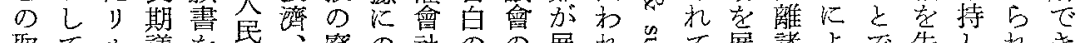

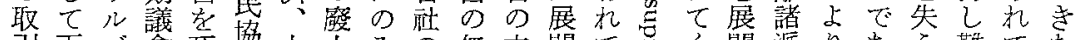

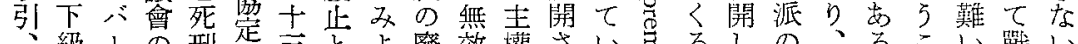

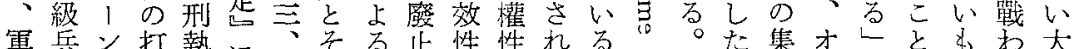

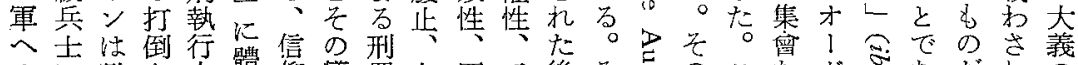

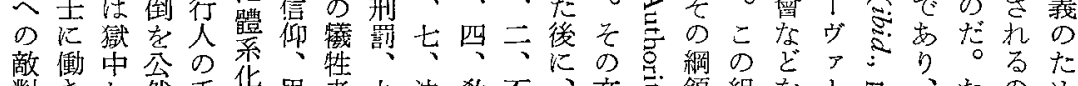
對き吕然手华思者九法数不、文岛領組を! ’、たのめ

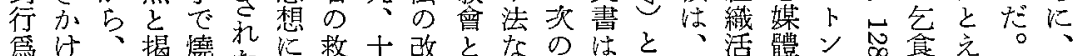

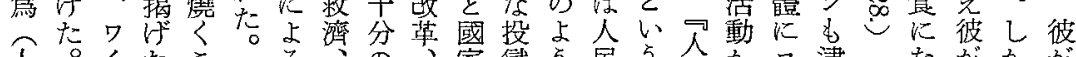

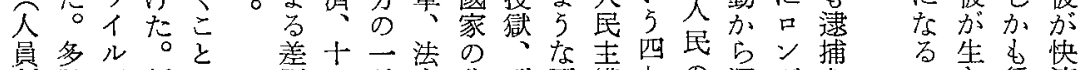

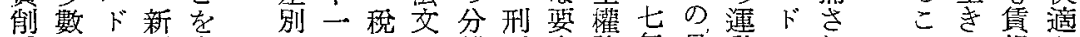
減のマ制命の、の㐫離罰求論年最動ンれるの銀さ

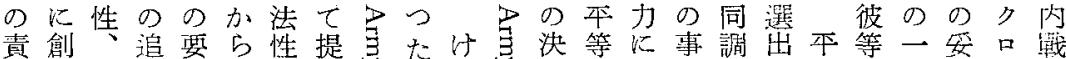

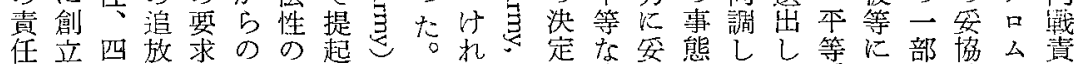

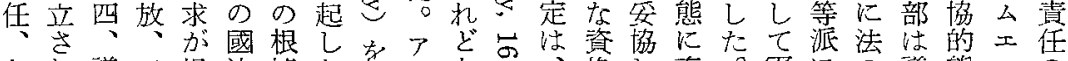
七机議三提法㟫た公 1 女念格し直。軍にの議態儿の

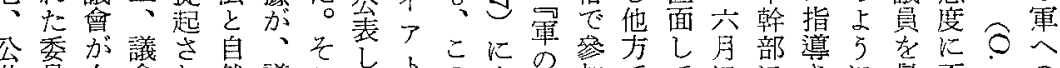

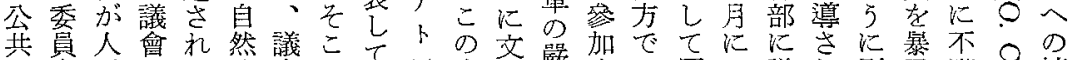

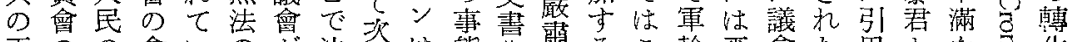

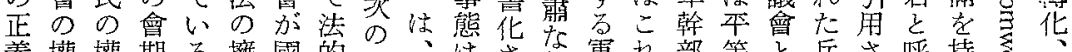

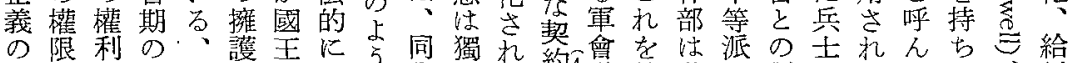

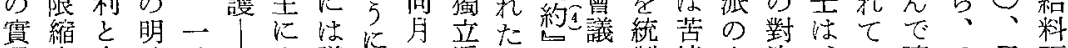

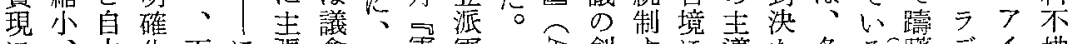

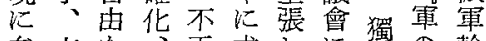
总六艺正求しに章の幹 慢、代三なめた從派提部 な租䒾、議らの屬の誈の 忩模生議員れ之卞立全

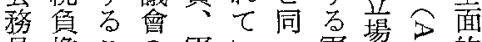
員擔この軍い一軍量的 の者々意にるの教軍苋な

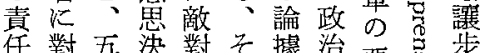
任對五決對そ提治要密步

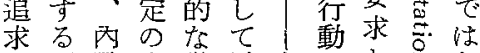
、國戰自議以古のと气な 父家中律員下く合し。市

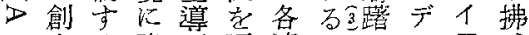

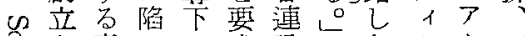

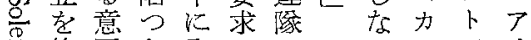
亭約圖た全しかいルンイ

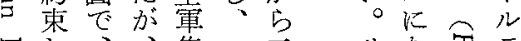

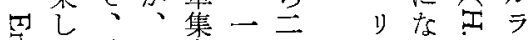

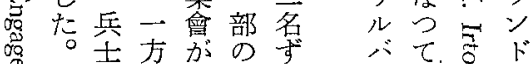

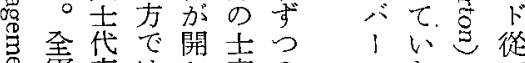
覃表心官の施等軍 集加兵れ代 90 軍命

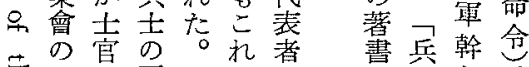

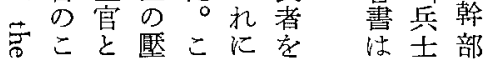


イのいのあり彼を動く巴たに表直抗!打立國军選

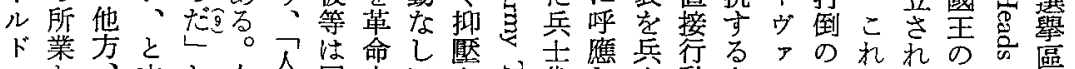

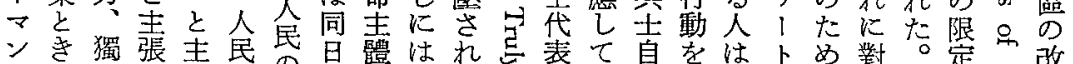

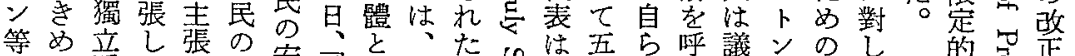

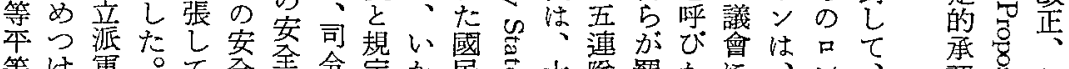

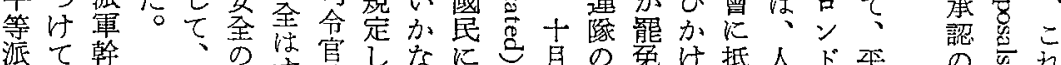

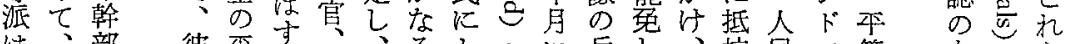

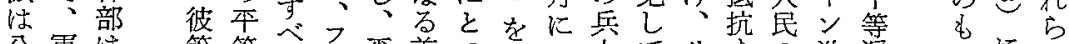
公軍は等等で

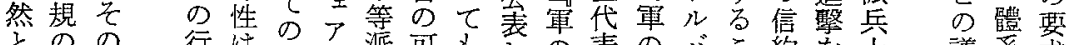

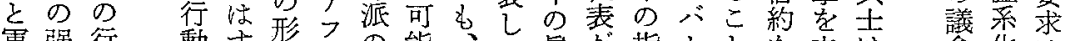

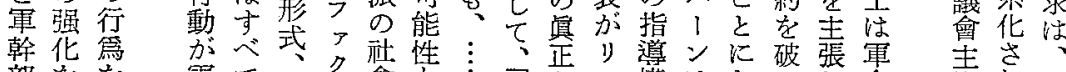

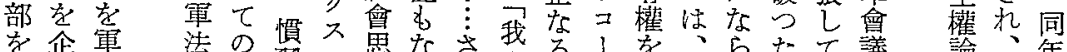
を企車法の䆩入思なさ我る、をるらたて議論、年 翡て分分 乙。列反

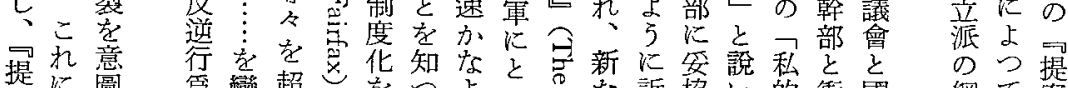

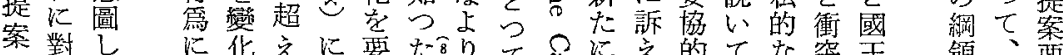

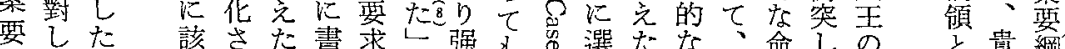

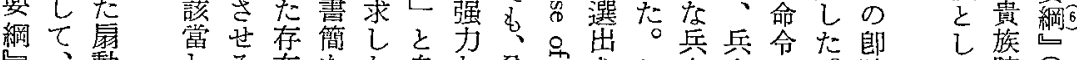

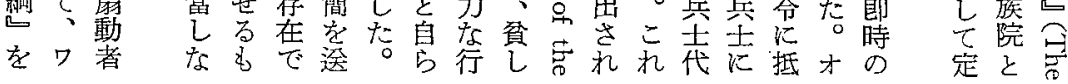

解後的否しすとによ法ア約國にたい二の立機卜解批

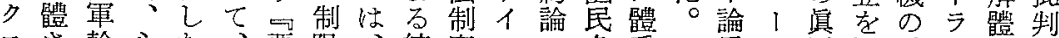
口さ幹心た、要限、統度アの各系こ爭の正深重ンをし

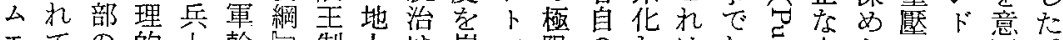

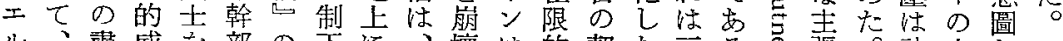
儿、萧感部の下に、壤は的契た言るき張。垪交しこ

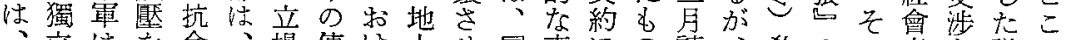

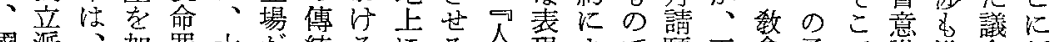

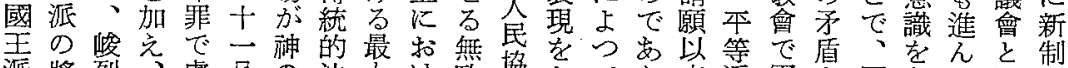
派將烈處月の法も沙政势とてり來派軍を軍急で國軍

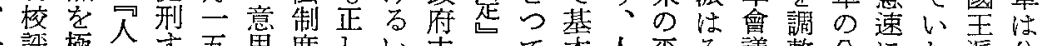

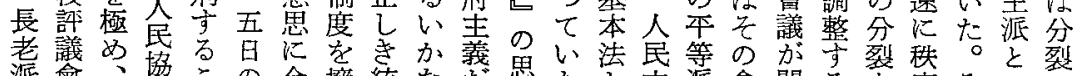

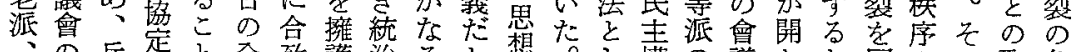
、高兵起全致護治ると想。之權の議かた问のの取危

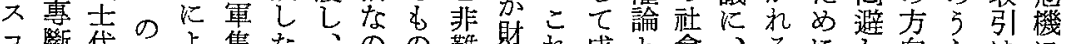

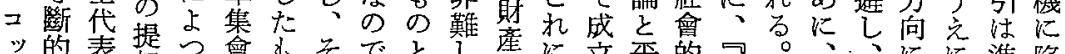

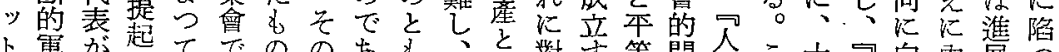

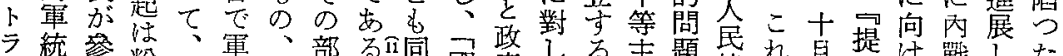

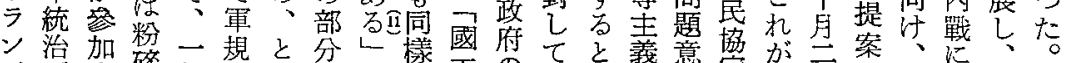

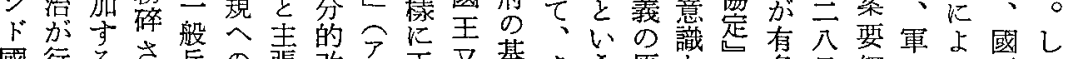

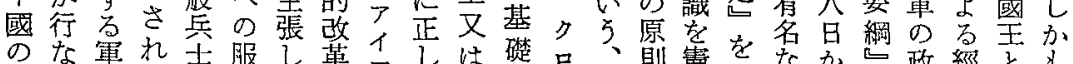

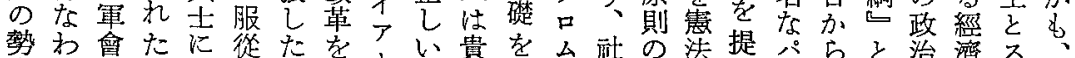

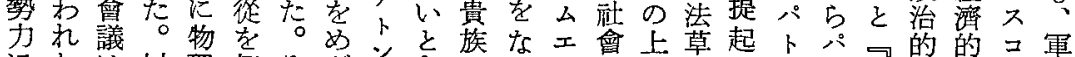

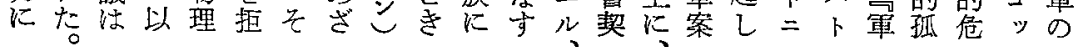




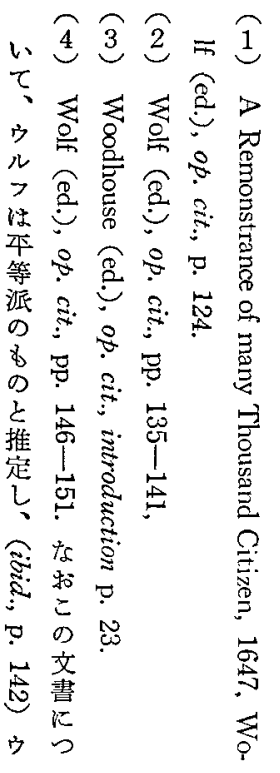

の四二はつあ家のそこキ的獨ノはしは

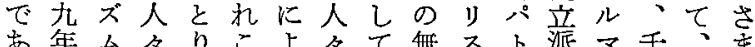
るのをを速れつはそ知トスにン年四れ

○丁批緼い彼て非れが的が接の王八て 个判拿方等利常吕知な權近斬國年坬 ルしさ法の用に最識殘力さと說の立 ラたせを事さ多大の酷者过呪を難し ンウ、あ情れいの裁をのた莇信局た ドオ粗るとて。宗性生衡。す奉に獨 戰了野こ意い彼敉官文策こるし對立 争ルにと圖る等活に出に机令處派 にワすをが。は動なす陷にブ國しの 對イる留、要通非のうこ竞對テ教て立 夺ンᄂ 万の時 $\vdots$ 寸的に查まを险てスとくを 兵主代經石な多官た警性、上長。聖

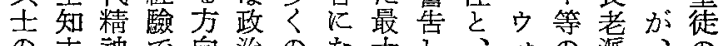
の主神で向治のな大乙落派、の

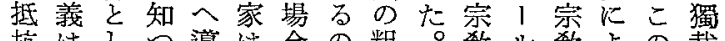
抗はしっ蔀は合の粗。教ル教よの裁 權、ててく、野次的口的万聖の 論四のいた迷通あと多良イラ宗趗思 に八ピるめ信俗る怠く心ンデ数㺈想 結年 = 0 の 的。邽のがは1的裁で 晶の1 最大なこに場逆、力迫の正

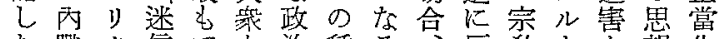
た戰タ信てを治種る员数を梖化

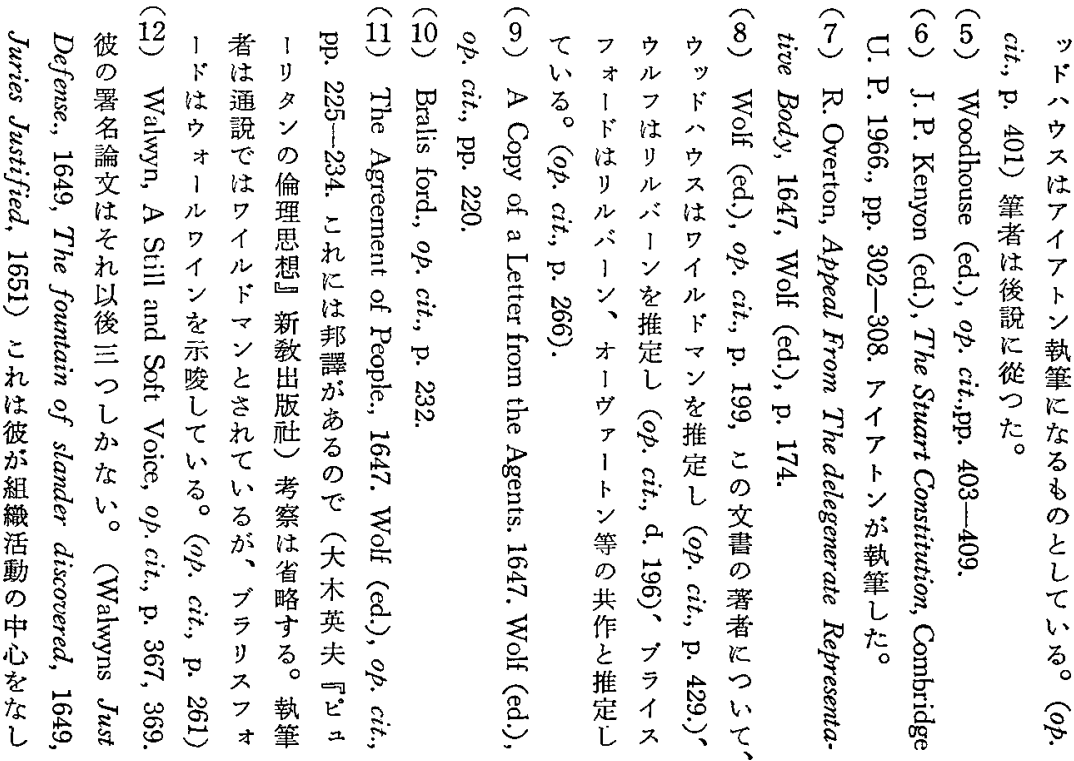


それ礼て張こ素きに等以間吉和をる金民

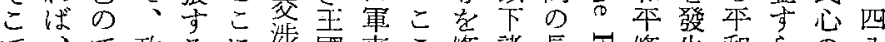
で、で政るに涉國事こ條諸長冚條生和らの八

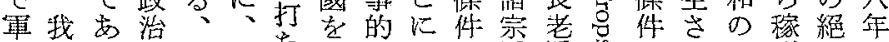

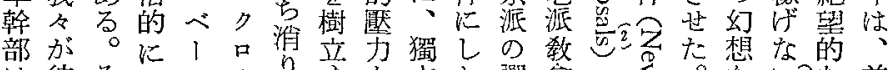

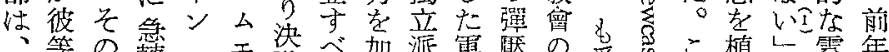

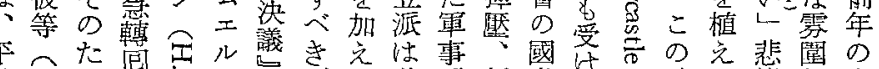

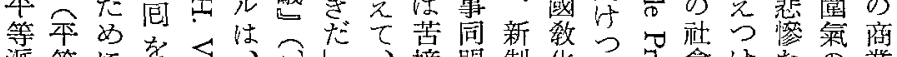

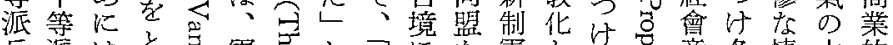

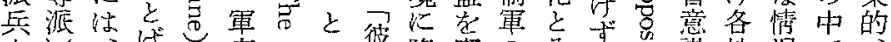

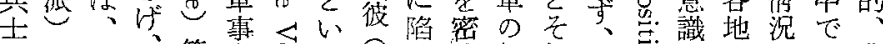

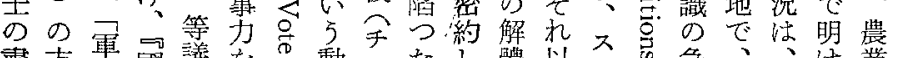

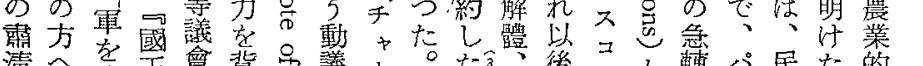

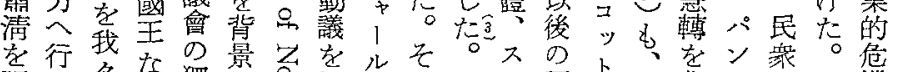

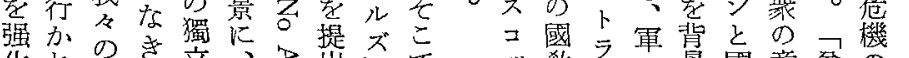

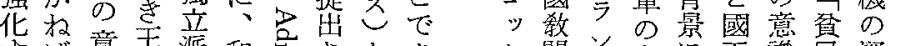

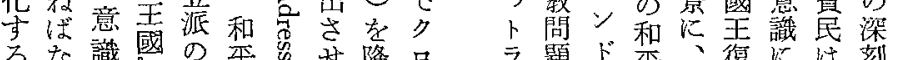

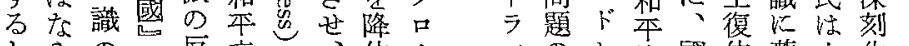

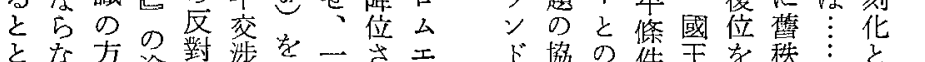

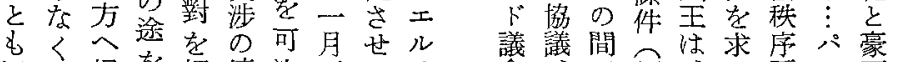

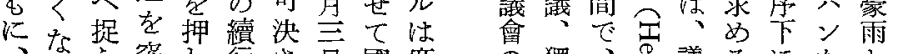

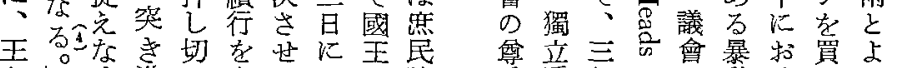

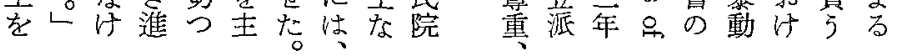

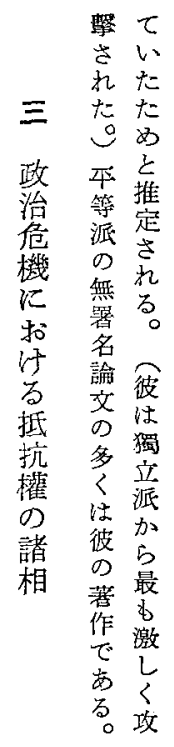

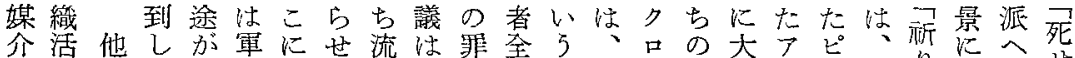

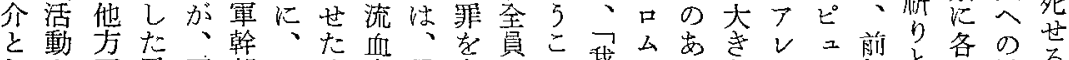

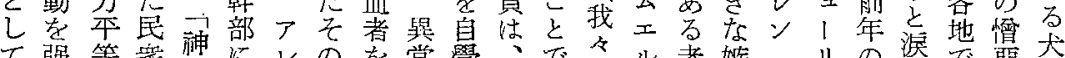

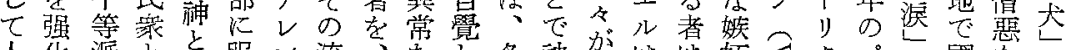

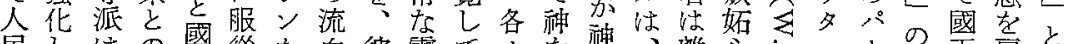

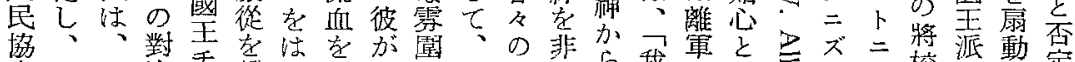

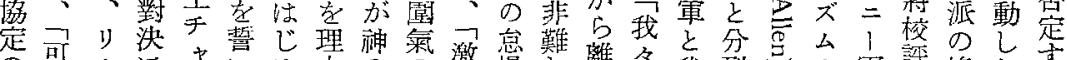

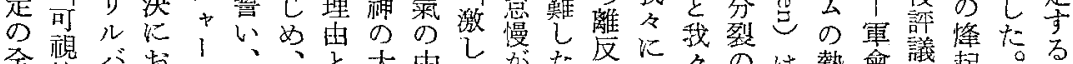

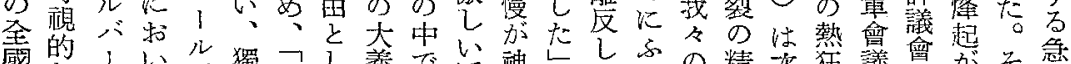

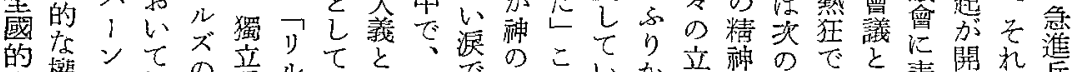

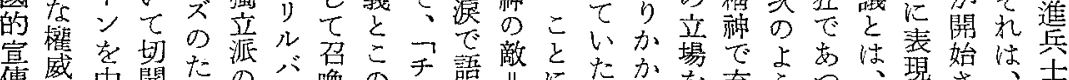

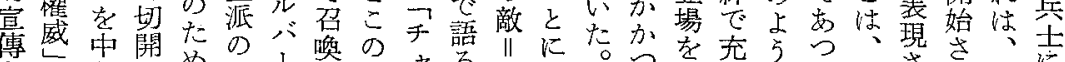

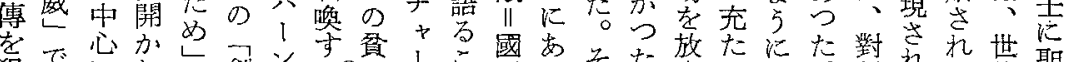

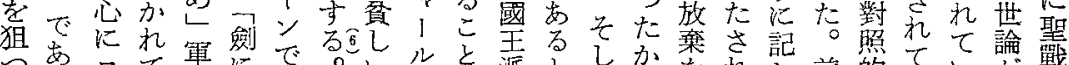

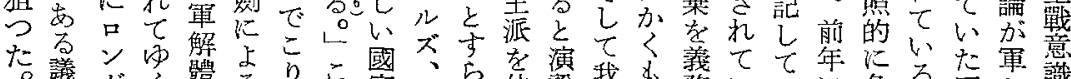
。議ドく體らりこ國、らを演我总義てて年にるた軍意

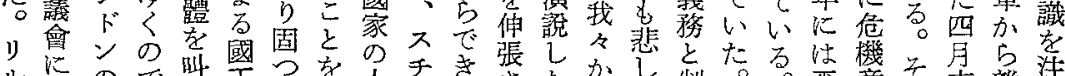

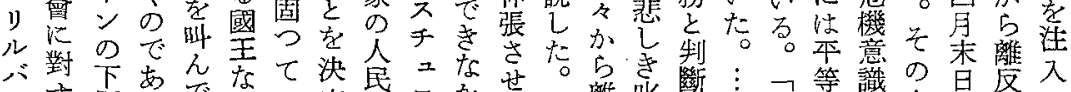

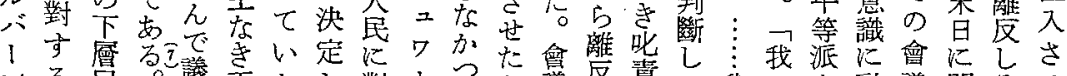

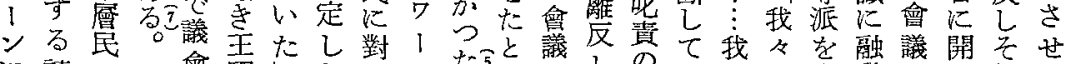

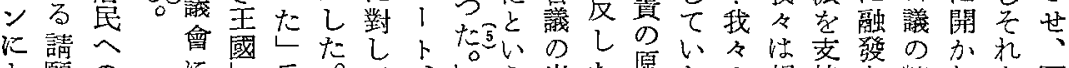
と愿のにし兵。て、しう出た原たの相持さ精れる國 つを組殺の立こ降舠會こ席と因し5互しれ神た背王 


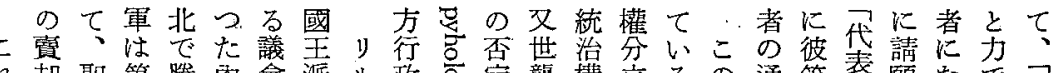

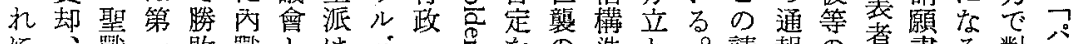

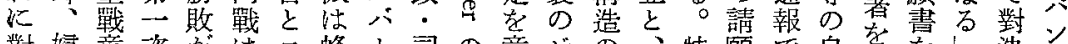

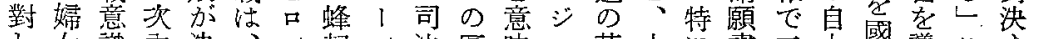

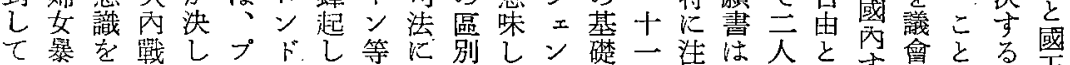

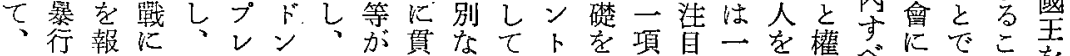

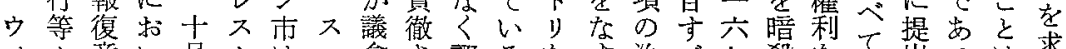
オ々意い月トはコ曾さ㒛るをす治べケ殺をて出つ㤹

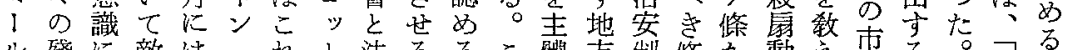

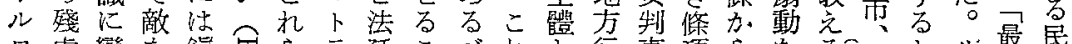

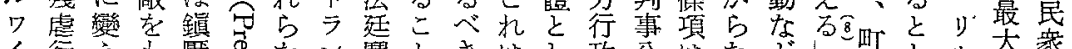

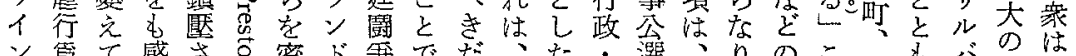

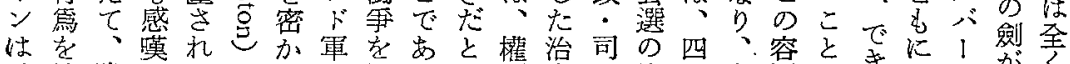

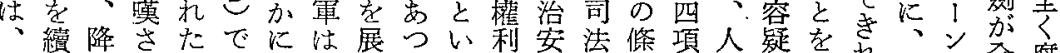

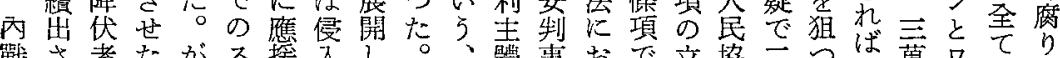

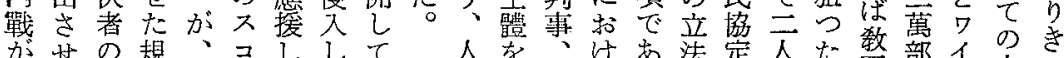

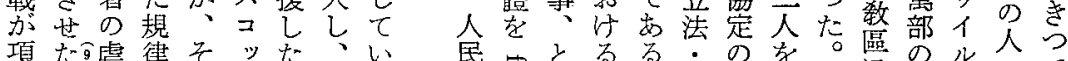

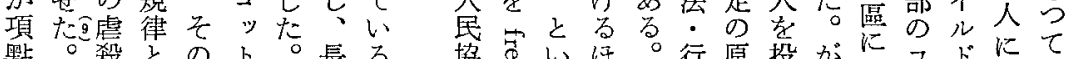

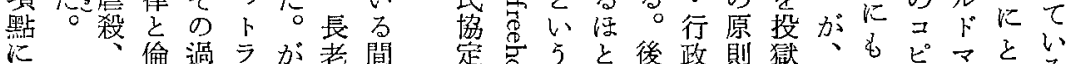

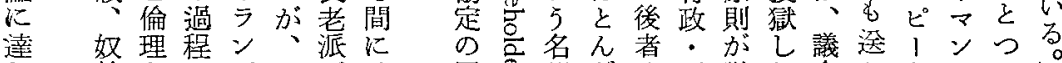

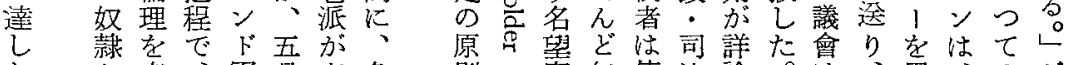

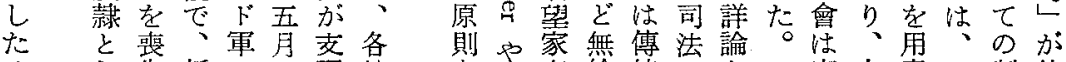

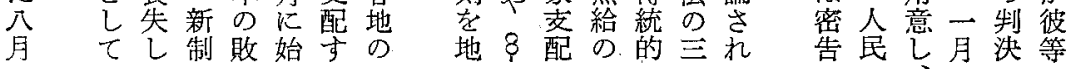

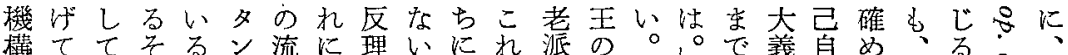

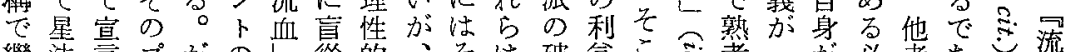

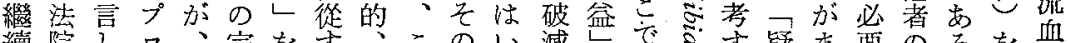

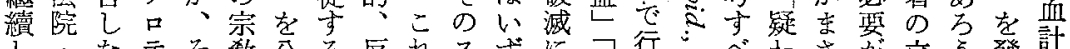

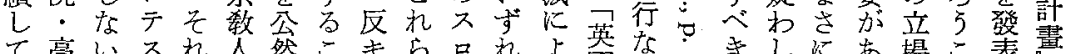
七高い及机人然こ

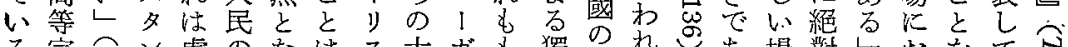

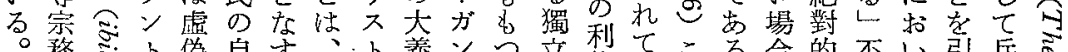

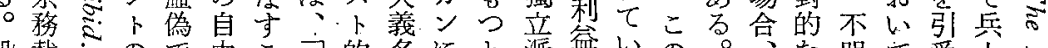

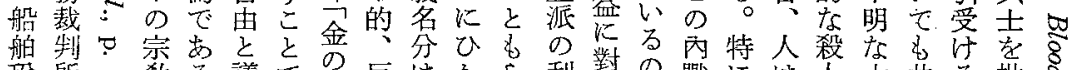

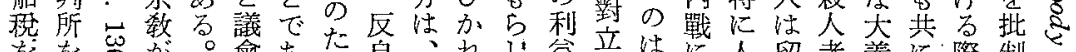

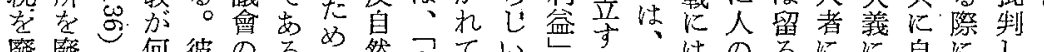

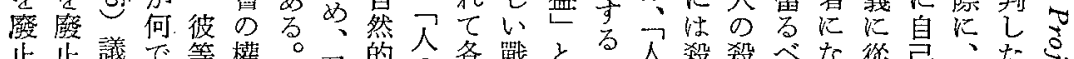

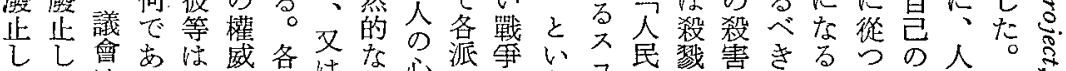

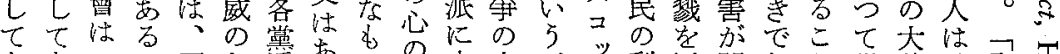

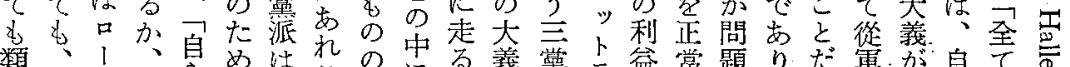

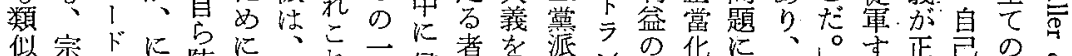

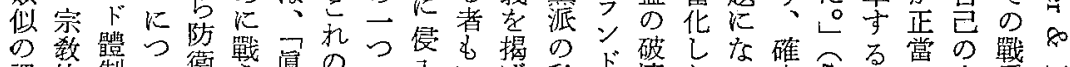

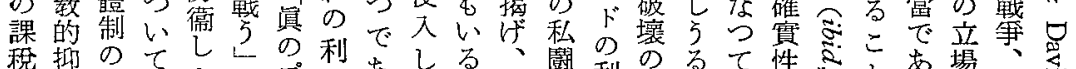

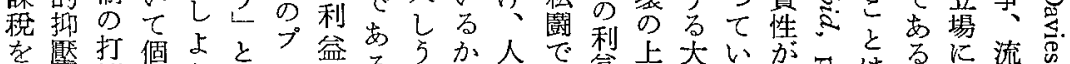

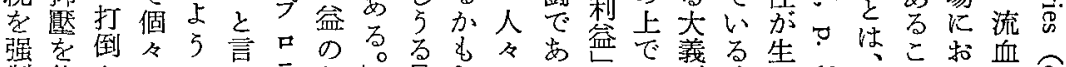

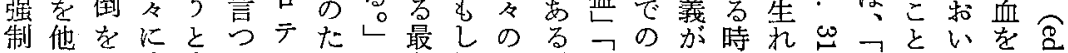

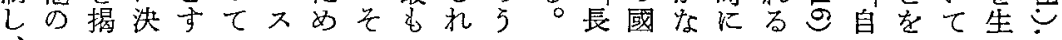


すし威の法のあ權よいはな的人表声る定の る害國貴 るたはの的ごる势 5 か、權抑底權融議權要でこと王族

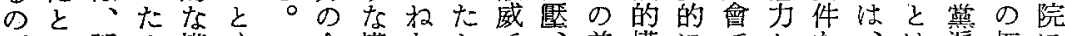

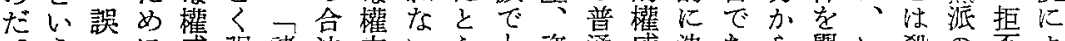

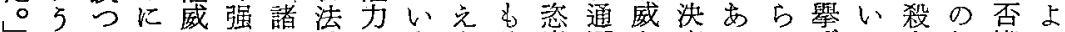
二理て戰に制君性のむ合々意選字定名のげか人相權る

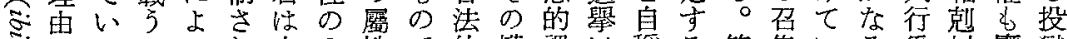

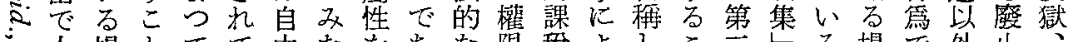
○場とてて由なを好な限挩よしこ二しる場で外止 々合を戰奉なら銳り權の、る、とにに。合市のさ裁

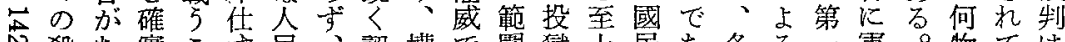

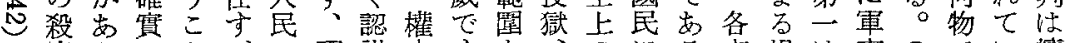

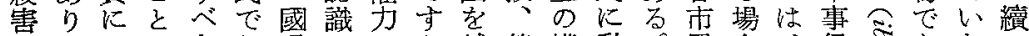
と、し

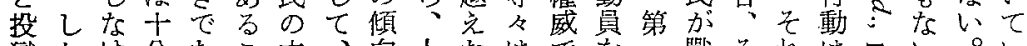

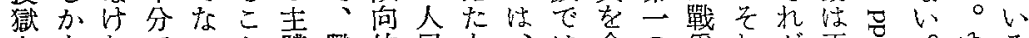

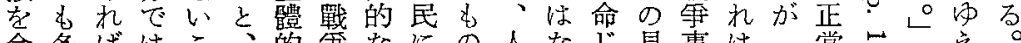

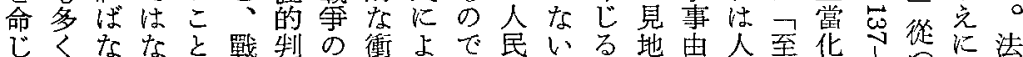

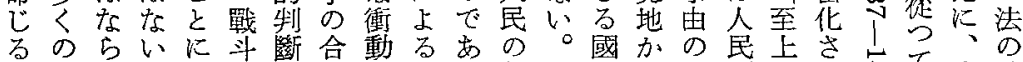

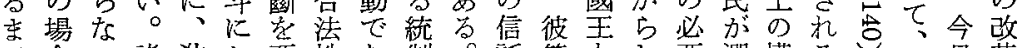

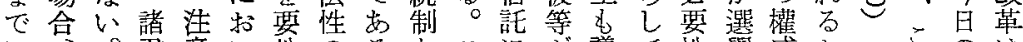

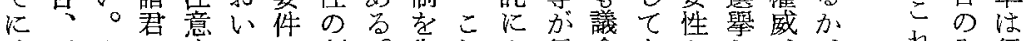

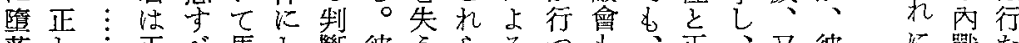
落し

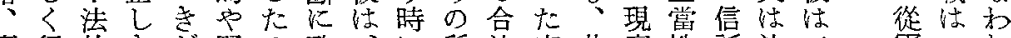

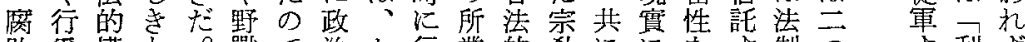

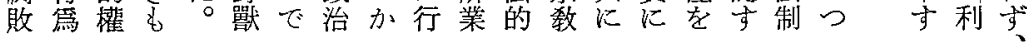

八たが役一法識覆と、開と几の存ら理のあ隷覺要

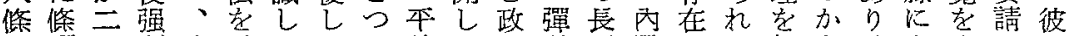

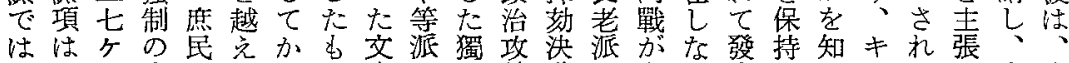
は、條廢院た、の書は立勢議恪い各しるリてし盲權 し國に歨の存後でを九派を、、地のさてるていた目力

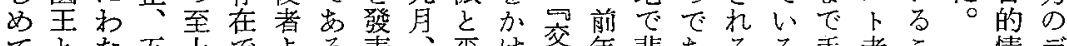

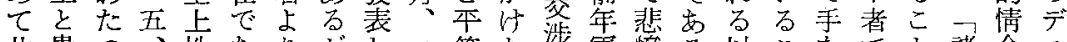

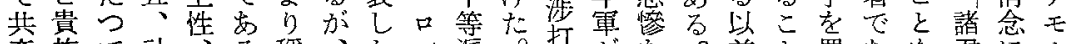

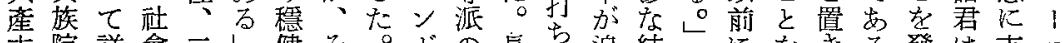

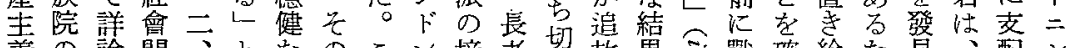
義の論問、をなのこン接老切放果吉戰確給な見、配シ

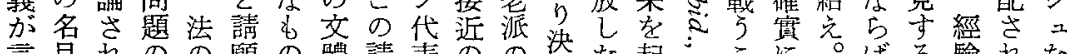

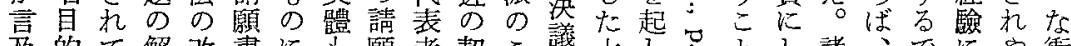

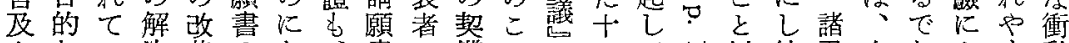

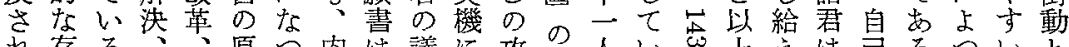

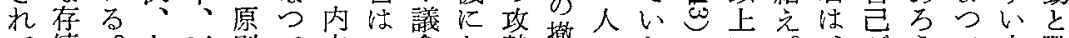

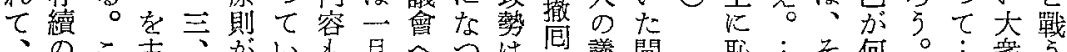

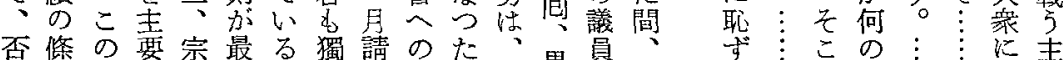

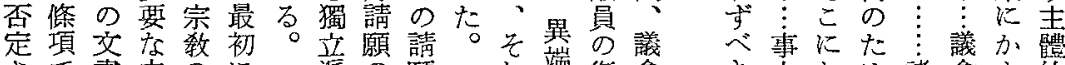

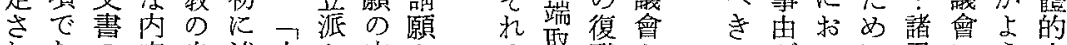

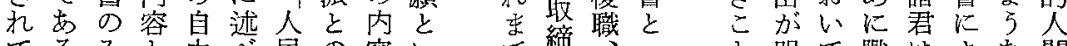

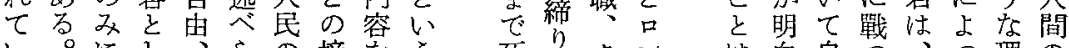

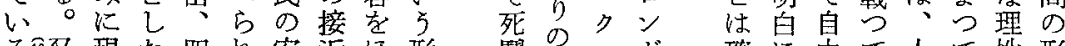

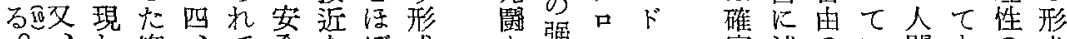

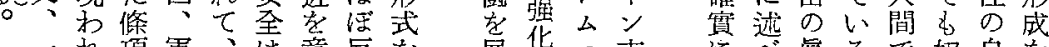

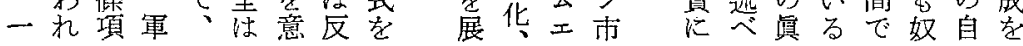


定が巽治條會そ國效ンたる何經定な無の年れ反ト

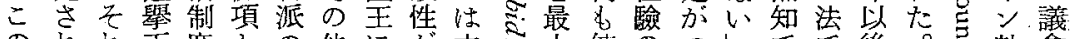

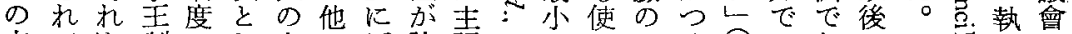

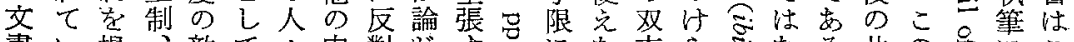

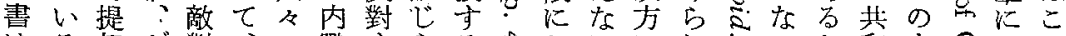

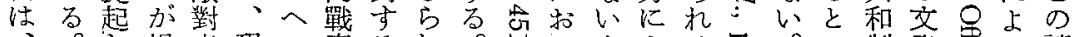

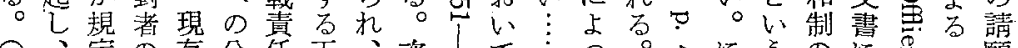

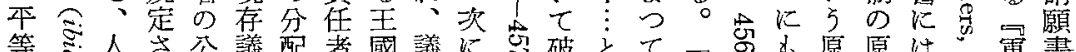

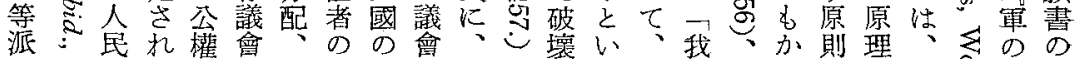

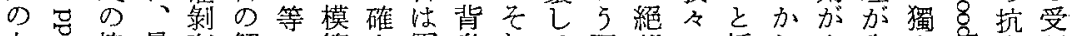

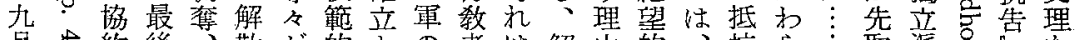

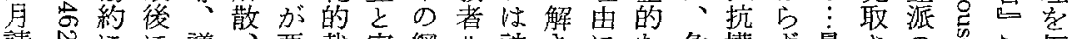

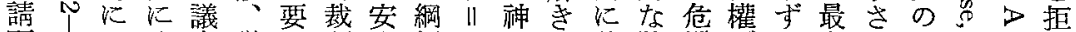

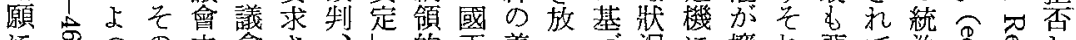

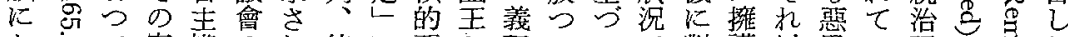

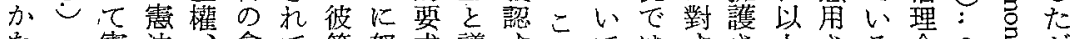

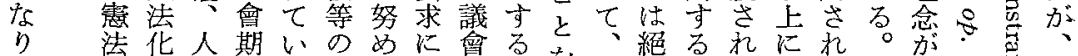

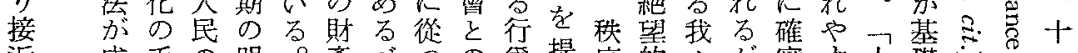

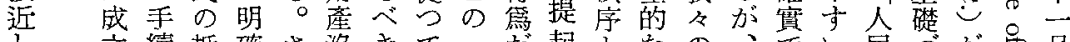

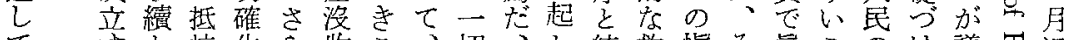

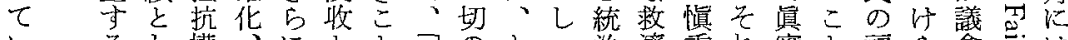

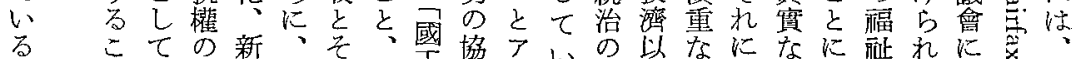

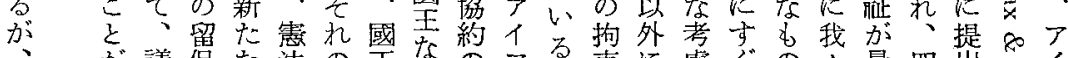

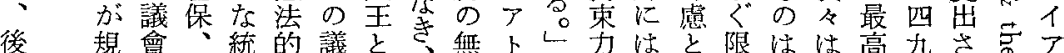

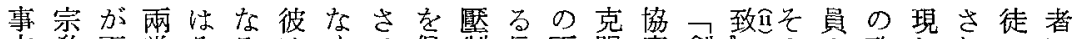

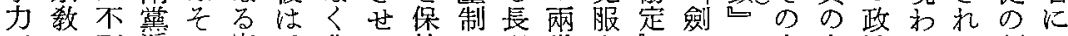

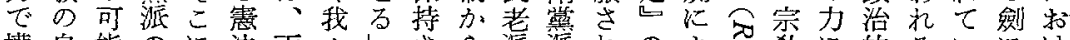

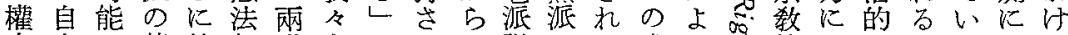
力由で基第起黨をこせの議のる成る年的よコるるるる

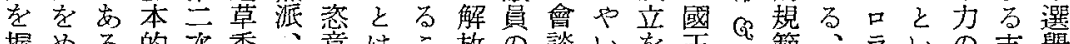
握める的次委、意はこ放の談い省王範、ラいの妾舉

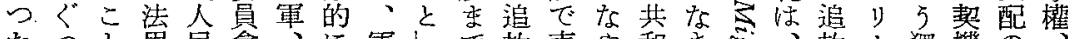
たつを思民會、に軍しで放表や和き品、放!獨機の

獨てに想協の議艾幹がはと面、制主な」でが立は方到 立果似の定創會配部必、國化崩の國乏・市十派、向會

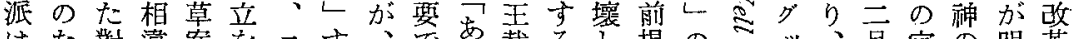

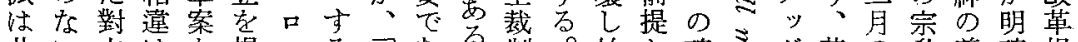

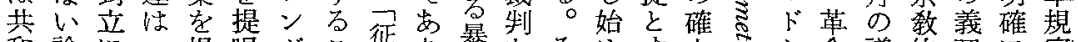

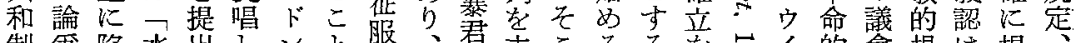

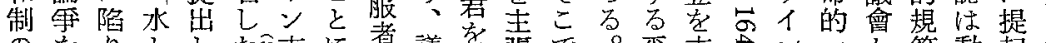

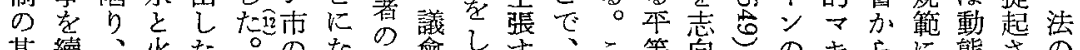

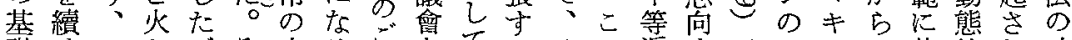

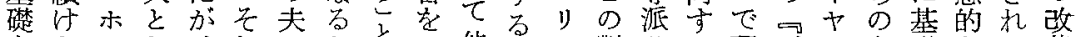

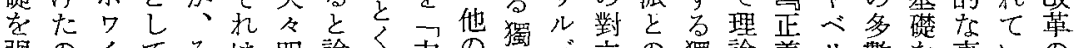
强のイてそは四論明力星立立の㯰諭義り數を事いの

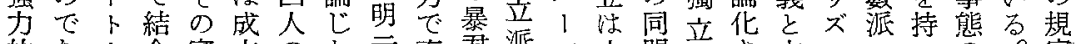

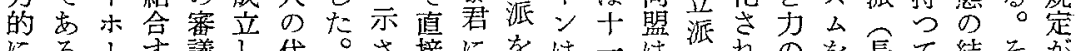

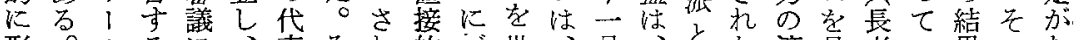

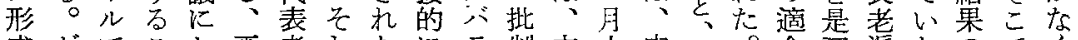

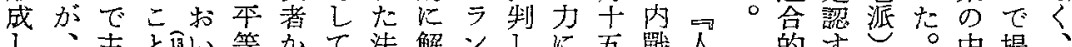

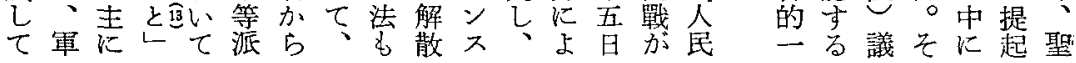




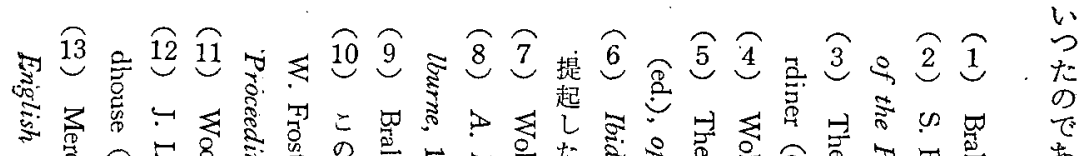

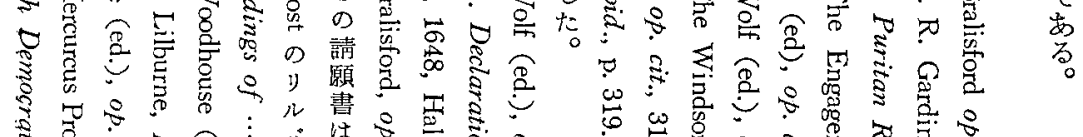

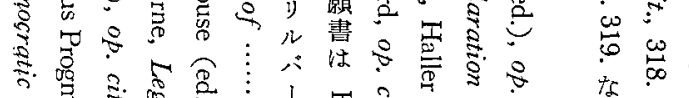

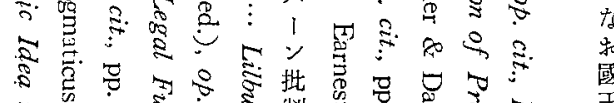

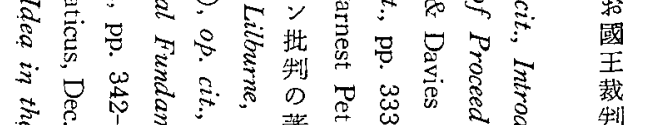

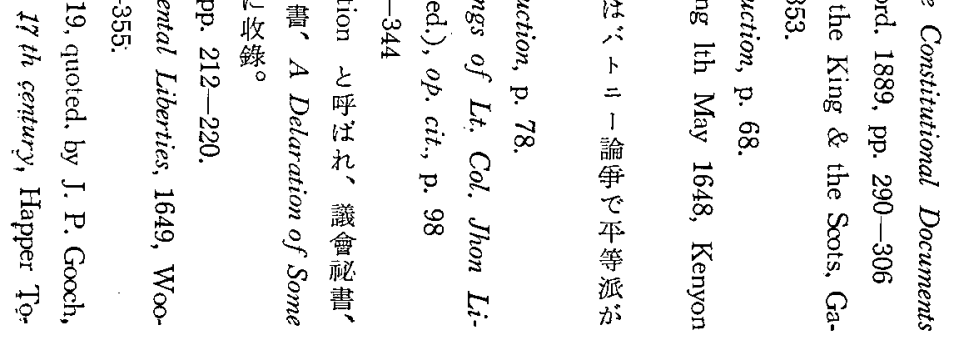

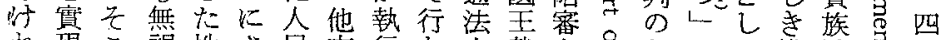

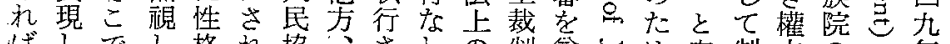

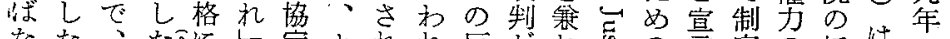

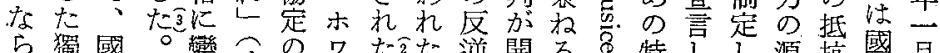

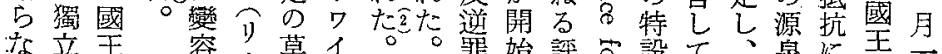

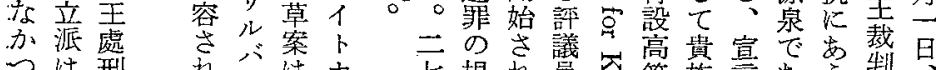

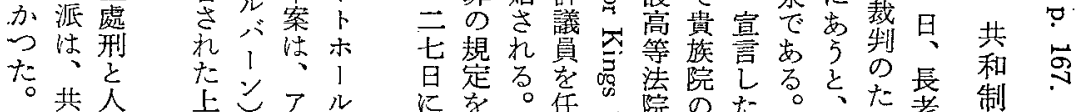

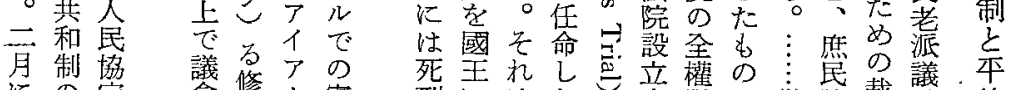

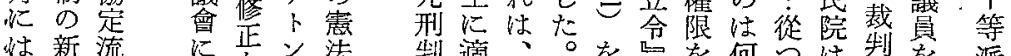

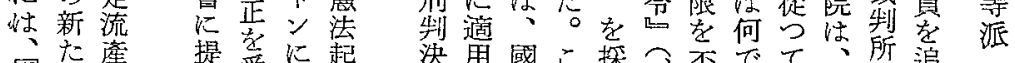

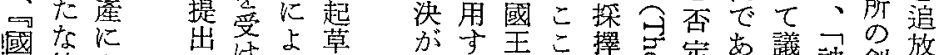

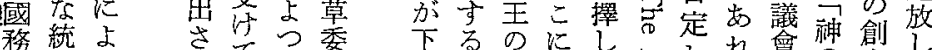

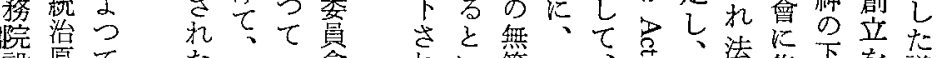
設愿てた口會机い答曰、六法集下を議

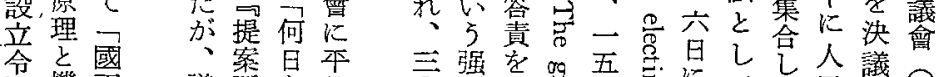

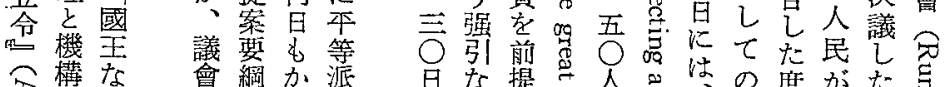

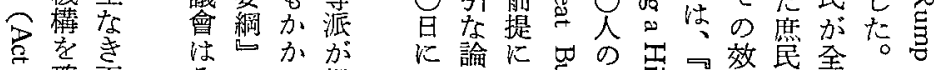

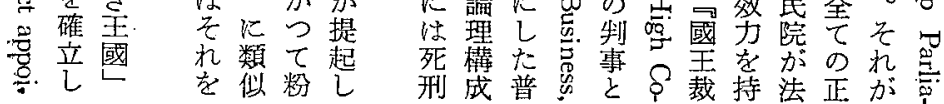




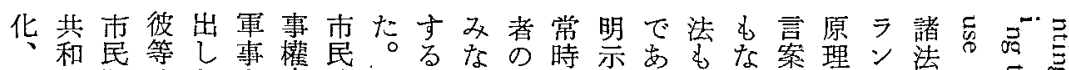

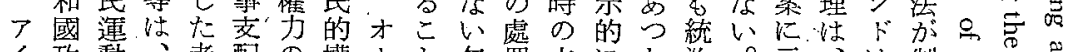

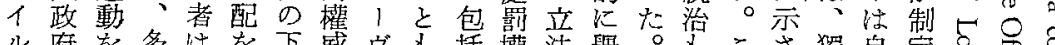

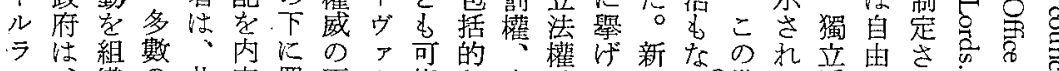

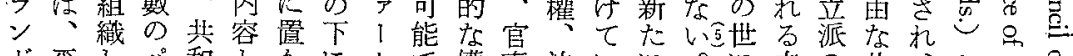

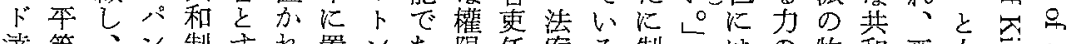

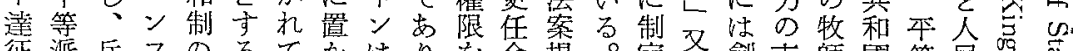

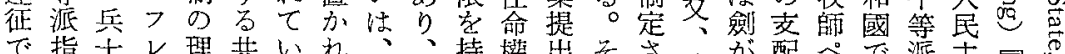

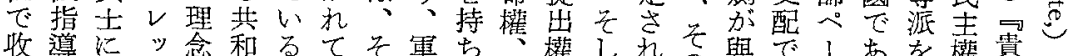

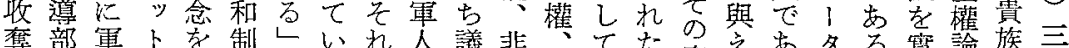

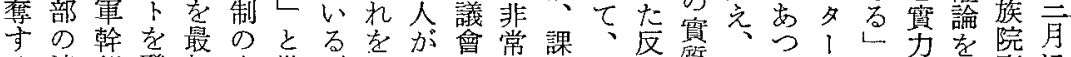

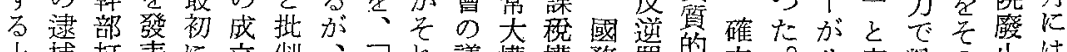

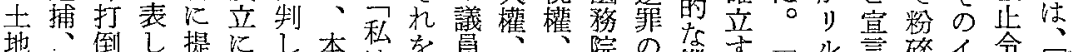

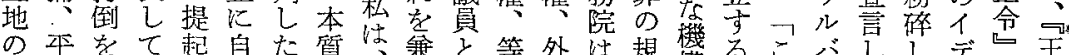

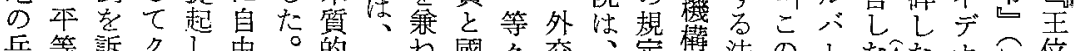

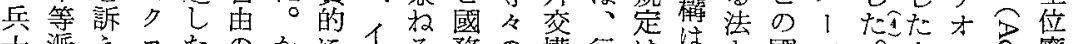

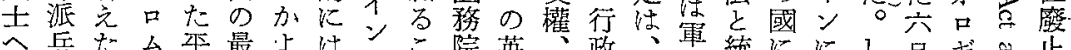

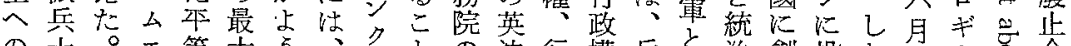

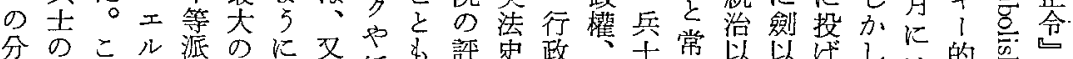

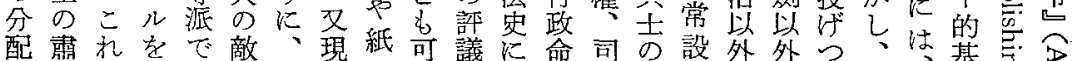

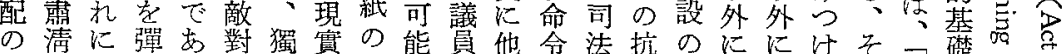

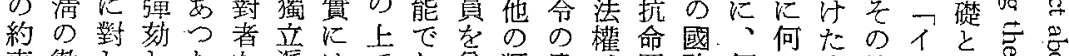

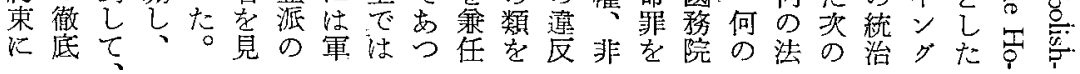

の异いこ事よし切にキは拘總れの世思才大礎叛イよ

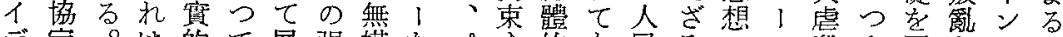

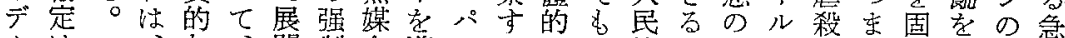

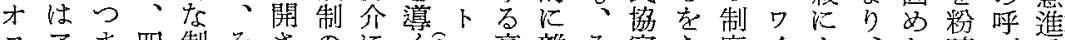

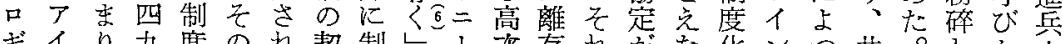
キ1り杂度のれ契制し!次存れ加な化ンつ共。乙か士

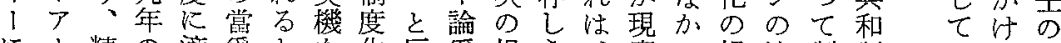

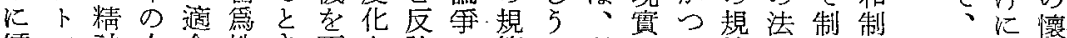

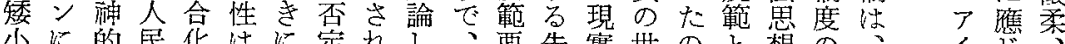

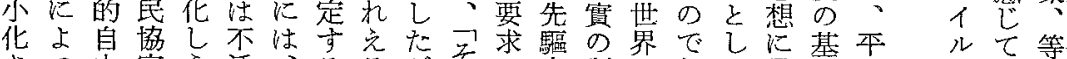

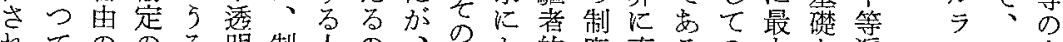

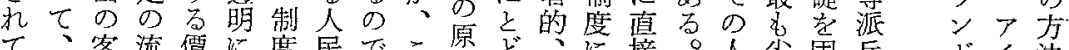
て、客流價に度民でこ原ぞ、接。人尖固兵ドイ法

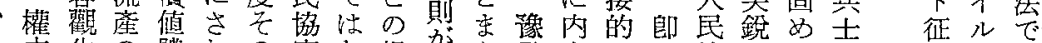

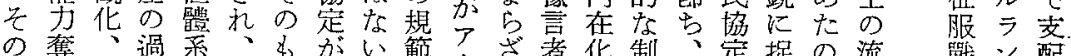

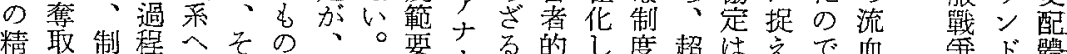

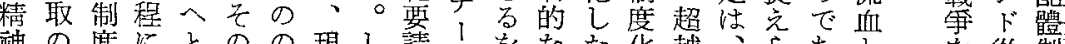

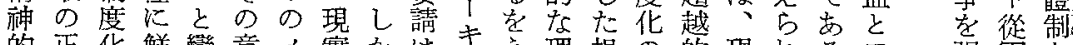

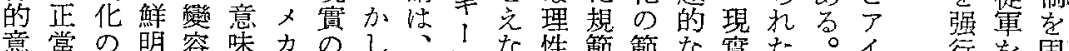

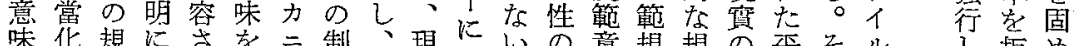

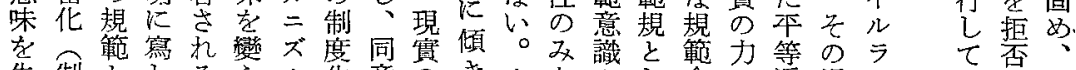
失制としる古么化意のき》をのし命の派渦ン

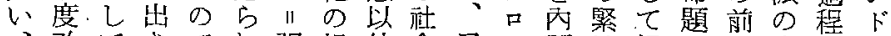
肇てさでれ强規外會アム面縛提とに自で佳 次革のれあて制範の意子工的か起し挫然良

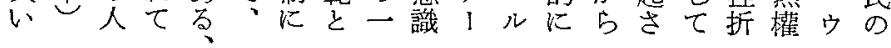
て否ウ 支たむ 配 部 1 の隔ル 基 の 
4.

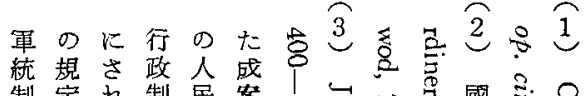

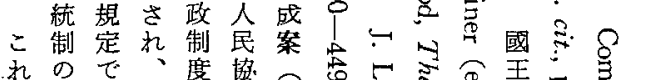

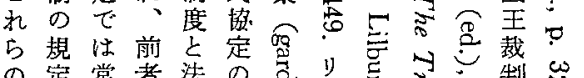

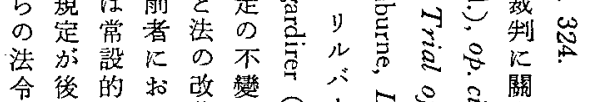

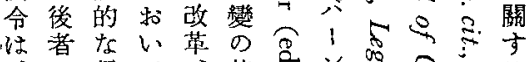

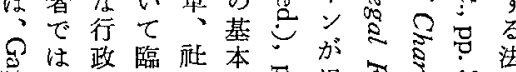

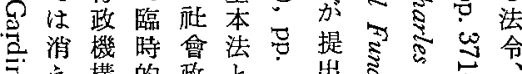

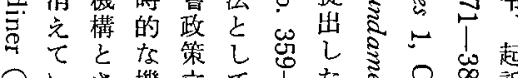

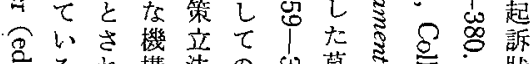

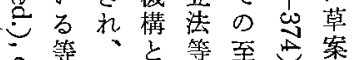

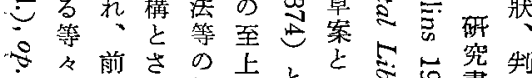

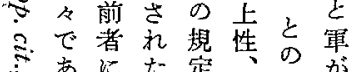

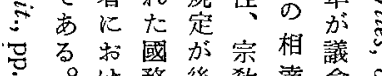

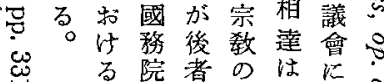

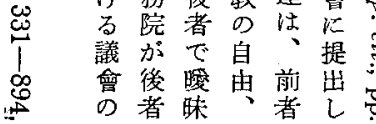

自の峾制けの於场現

由1法文れ

たレの思どト指强の

め琴想もピ摘制力

のマ念と平了しをの

强をの等思た否論

制內形背派想ご定理

制に成反のでとしの

居々持客々法あく距前

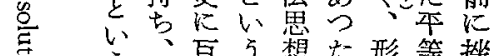

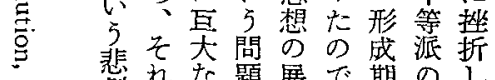

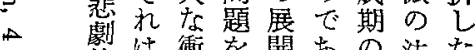

的㤬衝势開市法た

な山激銃之方資思

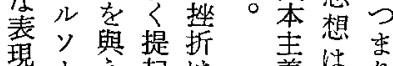

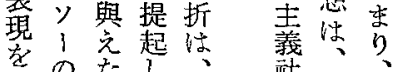

亡社社元近临摆同

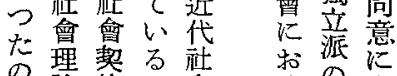

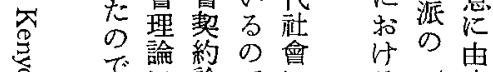

で䛉論て沈る之來

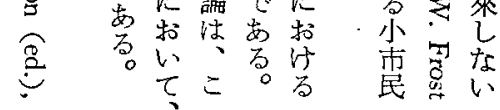

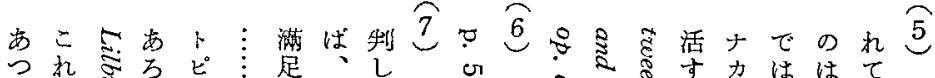

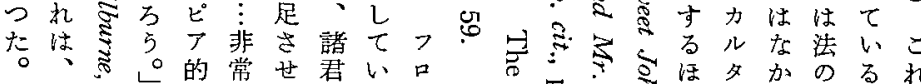

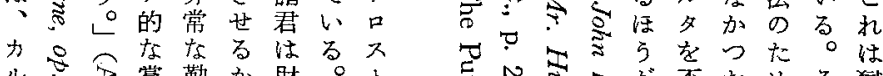

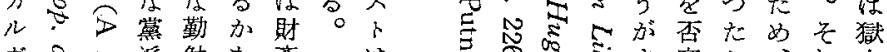

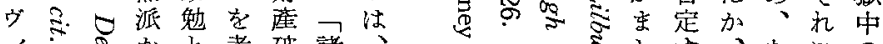

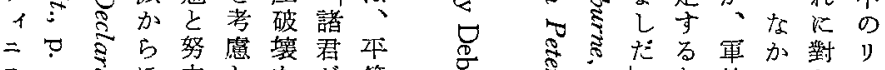

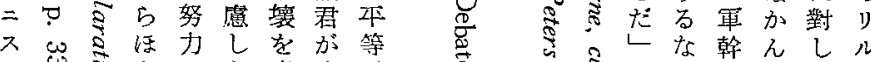

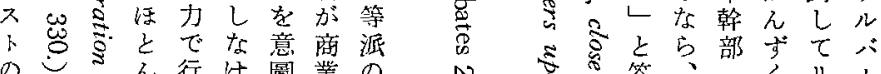

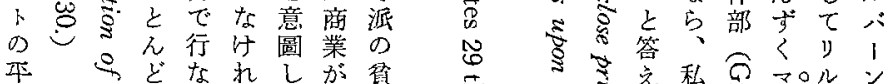

$$
\begin{aligned}
& \text { 等架勇わ隹な國民 } \\
& \text { 派密氣机ない家救 } \\
& \text { になる゙るらたに渭 } \\
& \text { 粼 けのなめとの }
\end{aligned}
$$

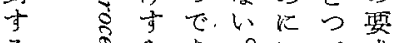

$$
\begin{aligned}
& \text { る。直。いて求 } \\
& \text { 典焉受彼か善を } \\
& \text { 型 }
\end{aligned}
$$

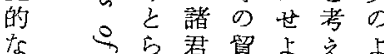

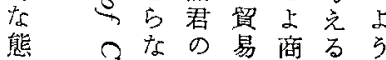

$$
\begin{aligned}
& \text { 度さ心こは人なと }
\end{aligned}
$$


ners.

The villages brought into the world by this policy contain the tendency toward the economical territory based on the land measurement system by koku (石), and may be recognized as administrative villages quite different in their character from those of agriculturalcooperative-bodies (農業步同體).

\section{An Introduction to the Study of the legal Ideas of the Levellers at the Time of Puritan Revolution \\ by Masayuki Koike}

S. B. Chrimes said that " the seventeenth century is the Heroic age in English constitutional History."

If this is true, we must take notice of the importance of the legal theories in the controveries upon the constitutional issues at the time, when we make a detailed study of the legal and political thoughts in England.

This article, from the point of view that a legal thought is sharped up on the basis of the interdependance between the legal idea and the legal system, deals with the lawreform-movement of the Levellers during the period from 1647 to 1649 and clarifies the significance of the theories among them. particulary that of W. Walwyn who was the most original rationalist of all their leaders.

The author argues how the idea of the fundamental human rights originating from the ethical rule of the separatists was embodied in the legal principle called "The Agreement of the People," the first written constitutional draft founded on the democratic social contract theory of the Levellers. But the draft failed to be a formal constitution, because it was inconsistent with the spirits or the age.

The author, explicating the process of the formation of the draft and its abandonment, concludes that the social contract theory based on the natural right was too idealistic to be a principle giving rise to a new legal system, although it had destroyed the old order.

\section{The Official Control over the Eta (稆多) by the Kyoto Deputy Governor and his Following in the Edo Era} by Koichi Nakazawa and Hiroshi Kobayashi

The aim of this essay is to describe briefly the significant feature of the official control over the lowly (Eta 橫多) by the Kyto Deputy Governor (Kyoto-shoshidai 京都所司代) 